\title{
Summary and synthesis of Changing Cold Regions Network (CCRN) research in the interior of western Canada - Part 2: Future change in cryosphere, vegetation, and hydrology
}

Chris M. DeBeer ${ }^{1,2}$, Howard S. Wheater ${ }^{1,2,3}$, John W. Pomeroy ${ }^{1,2}$, Alan G. Barr ${ }^{2,4}$, Jennifer L. Baltzer ${ }^{5}$, Jill F. Johnstone ${ }^{6,7}$, Merritt R. Turetsky ${ }^{8,9}$, Ronald E. Stewart ${ }^{10}$, Masaki Hayashi ${ }^{11}$, Garth van der Kamp ${ }^{2}$, Shawn Marshall ${ }^{12,13}$, Elizabeth Campbell ${ }^{14}$, Philip Marsh ${ }^{15}$, Sean K. Carey ${ }^{16}$, William L. Quinton ${ }^{15}$, Yanping Li ${ }^{2}$, Saman Razavi $^{2}$, Aaron Berg ${ }^{17}$, Jeffrey J. McDonnell ${ }^{2,18}$, Christopher Spence ${ }^{19}$, Warren D. Helgason ${ }^{20}$, Andrew M. Ireson ${ }^{2}$, T. Andrew Black ${ }^{21}$, Mohamed Elshamy ${ }^{1,2}$, Fuad Yassin ${ }^{1,2}$, Bruce Davison ${ }^{19}$, Allan Howard ${ }^{22}$, Julie M. Thériault ${ }^{23}$, Kevin Shook ${ }^{1}$, Michael N. Demuth ${ }^{1,24,25}$, and Alain Pietroniro ${ }^{19}$

${ }^{1}$ Centre for Hydrology, University of Saskatchewan, Saskatoon, Saskatchewan, Canada

${ }^{2}$ Global Institute for Water Security, University of Saskatchewan, Saskatoon, Saskatchewan, Canada

${ }^{3}$ Department of Civil and Environmental Engineering, Imperial College London, London, United Kingdom

${ }^{4}$ Climate Research Division, Environment and Climate Change Canada, Saskatoon, Saskatchewan, Canada

${ }^{5}$ Biology Department, Wilfrid Laurier University, Waterloo, Ontario, Canada

${ }^{6}$ Department of Biology, University of Saskatchewan, Saskatoon, Saskatchewan, Canada

${ }^{7}$ Institute of Arctic Biology, University of Alaska Fairbanks, Fairbanks, Alaska, United States

${ }^{8}$ Department of Integrative Biology, University of Guelph, Guelph, Ontario, Canada

${ }^{9}$ Department of Ecology and Evolutionary Biology, Institute of Arctic and Alpine Research,

University of Colorado Boulder, Boulder, Colorado, United States

${ }^{10}$ Department of Environment and Geography, University of Manitoba, Winnipeg, Manitoba, Canada

${ }^{11}$ Department of Geoscience, University of Calgary, Calgary, Alberta, Canada

${ }^{12}$ Department of Geography, University of Calgary, Calgary, Alberta, Canada

${ }^{13}$ Environment and Climate Change Canada, Gatineau, Quebec, Canada

${ }^{14}$ Natural Resources Canada, Canadian Forest Service, Pacific Forestry Centre, Victoria, British Columbia, Canada

${ }^{15}$ Cold Regions Research Centre, Wilfrid Laurier University, Waterloo, Ontario, Canada

${ }^{16}$ School of Geography and Earth Sciences, McMaster University, Hamilton, Ontario, Canada

${ }^{17}$ Department of Geography, Environment and Geomatics, University of Guelph, Guelph, Ontario, Canada

${ }^{18}$ School of Geography, Earth \& Environmental Sciences, University of Birmingham,

Edgbaston, Birmingham, United Kingdom

${ }^{19}$ National Hydrology Research Centre, Environment and Climate Change Canada, Saskatoon, Saskatchewan, Canada

${ }^{20}$ Chemical and Biological Engineering, University of Saskatchewan, Saskatoon, Saskatchewan, Canada

${ }^{21}$ Faculty of Land and Food Systems, University of British Columbia, Vancouver, British Columbia, Canada

${ }^{22}$ Agriculture and Agri-Food Canada, Regina, Saskatchewan, Canada

${ }^{23}$ Centre ESCER, Department of Earth and Atmospheric Sciences,

Université du Québec à Montréal, Montréal, Quebec, Canada

${ }^{24}$ Cryosphere Geoscience Section, Geological Survey of Canada, Ottawa, Ontario, Canada

${ }^{25}$ Northern and High Country Weather Impacts Laboratory, University of Victoria, Victoria, British Columbia, Canada

Correspondence: Chris M. DeBeer (chris.debeer@usask.ca)

Received: 24 September 2020 - Discussion started: 17 October 2020

Revised: 19 January 2021 - Accepted: 26 February 2021 - Published: 9 April 2021 
Abstract. The interior of western Canada, like many similar cold mid- to high-latitude regions worldwide, is undergoing extensive and rapid climate and environmental change, which may accelerate in the coming decades. Understanding and predicting changes in coupled climate-landhydrological systems are crucial to society yet limited by lack of understanding of changes in cold-region process responses and interactions, along with their representation in most current-generation land-surface and hydrological models. It is essential to consider the underlying processes and base predictive models on the proper physics, especially under conditions of non-stationarity where the past is no longer a reliable guide to the future and system trajectories can be unexpected. These challenges were forefront in the recently completed Changing Cold Regions Network (CCRN), which assembled and focused a wide range of multi-disciplinary expertise to improve the understanding, diagnosis, and prediction of change over the cold interior of western Canada. CCRN advanced knowledge of fundamental cold-region ecological and hydrological processes through observation and experimentation across a network of highly instrumented research basins and other sites. Significant efforts were made to improve the functionality and process representation, based on this improved understanding, within the finescale Cold Regions Hydrological Modelling (CRHM) platform and the large-scale Modélisation Environmentale Communautaire (MEC) - Surface and Hydrology (MESH) model. These models were, and continue to be, applied under past and projected future climates and under current and expected future land and vegetation cover configurations to diagnose historical change and predict possible future hydrological responses. This second of two articles synthesizes the nature and understanding of cold-region processes and Earth system responses to future climate, as advanced by CCRN. These include changing precipitation and moisture feedbacks to the atmosphere; altered snow regimes, changing balance of snowfall and rainfall, and glacier loss; vegetation responses to climate and the loss of ecosystem resilience to wildfire and disturbance; thawing permafrost and its influence on landscapes and hydrology; groundwater storage and cycling and its connections to surface water; and stream and river discharge as influenced by the various drivers of hydrological change. Collective insights, expert elicitation, and model application are used to provide a synthesis of this change over the CCRN region for the late 21 st century.

\section{Introduction and objective}

The interior of western Canada is a region undergoing rapid, widespread, and severe hydro-climatic and environmental change. This region is emblematic of the scientific and societal challenges in cold regions around the world where snow, ice, and frozen soils dominate water-cycling processes. Parts of western and northern Canada have experienced some of the highest rates of climate warming anywhere in the world (IPCC, 2013; Bush and Lemmen, 2019), and there have been systematic patterns of change in climate regime and cryospheric response (DeBeer et al., 2016), including a shift in the phase of precipitation $(P)$ toward more rain and less snow, earlier snowmelt and decreasing extent, duration, and maximum depth of seasonal snow cover, retreating glaciers, warming and thawing permafrost, declining ice cover period on lakes and rivers, and an earlier spring freshet. Against this backdrop of change, western Canada has been subjected to a series of recent, and in some instances record-breaking, extreme events such as floods, droughts, and wildfires. Human interventions and land and water management have also affected the environment and river systems, with infrastructure developments such as dams, diversions, and irrigation networks, along with industrialization, agricultural development, and urbanization, thereby altering natural ecosystems and water cycling. Future projections of warmer climate, altered $P$ phase and patterns, and more extreme events (Bush and Lemmen, 2019; Stewart et al., 2019), together with increasing human pressures, indicate that the region will continue to undergo rapid change to conditions never before experienced, posing difficult management and decision-making challenges (e.g., Razavi et al., 2020).

Improved understanding and prediction of the changes in coupled climate-land-hydrological systems are crucial for managing land and water systems and informing governance and policy direction here and in other similar regions globally. The processes of change in cold regions are manifold and complex, and there is significant uncertainty with the prediction of future change. Often, modelling and projections of hydrological change are based on over-simplistic or empirical approaches and models that fail to adequately capture the interconnected process drivers and responses. It is unclear to what extent the model structures and parameterizations are valid under highly non-stationary conditions and hence whether the results are meaningful under future climates and land and vegetation cover states. There has been much speculation about how cold regions will change, but, in many cases, this has not been based on appropriate process understanding, which is itself limited.

These issues and challenges were forefront in the goals of the recently completed Changing Cold Regions Network (CCRN, http://www.ccrnetwork.ca/, last access: 6 April 2021), described by DeBeer et al. $(2015,2016)$ and Stewart et al. (2019). CCRN aimed to integrate existing and new sources of data with improved predictive and observational tools to understand, diagnose, and predict interactions amongst the cryospheric, ecological, hydrological, and climatic components of the changing Earth system at multiple scales. Its specific geographic focus has been on the cold in- 
terior of western Canada, and in particular, the two major river systems of the region - the Saskatchewan and Mackenzie River Basins (Fig. 1). The overall science objectives of CCRN were to

1. document and evaluate observed Earth system change, including hydrological, ecological, cryospheric, and atmospheric components over a range of scales from local observatories to biome and regional scales;

2. improve understanding and diagnosis of local-scale change by developing new and integrative knowledge of Earth system processes, incorporating these processes into a suite of process-based integrative models and using the models to better understand Earth system change;

3. improve large-scale atmospheric and hydrological models for river basin-scale modelling and prediction to better account for the changing Earth system and its atmospheric feedbacks; and

4. analyze and predict regional and large-scale variability and change, focusing on the governing factors for the observed trends and variability in large-scale aspects of the Earth system and their representation in current models and the projections of regional-scale effects of Earth system change on climate, land and water resources.

Key to the success of the network was the ability to observe and diagnose change across the region and hence provide a platform of data (e.g., see https://essd.copernicus.org/ articles/special_issue901.html, last access: 6 April 2021) and scientific insights to inform model development and application for the analysis and prediction of change. A multiscale observatory was developed, based where possible on existing experimental sites with historical data records (Fig. 1), and this formed the heart of the program, enabling process responses and interactions to be monitored across the different ecological regions and at the scales of small river basins and major river systems. In conjunction with the experimental and observational program, modelling research aimed at improving the capability of fine- and large-scale models to represent key cold-region processes and to diagnose the complex and interacting factors underlying the observed changes over the CCRN region. Finally, these models have begun to be used, in conjunction with expert elicitation, to examine likely future system trajectories for the purposes of informing management and policy and addressing other stakeholder concerns. In doing so, CCRN assembled and focused a wide range and depth of multi-disciplinary expertise to address the network's aims and to develop insights into the process controls across the CCRN domain.

This article draws together the expert understanding and process insights from CCRN, together with modelling results at different scales, to examine the key drivers of change and to highlight the most likely anticipated future system trajectories across the interior of western Canada. This follows Part 1 (Stewart et al., 2019), which synthesized CCRN's collective assessments of future climate conditions and the associated seasonal patterns, along with particular $P$ - and temperature-related phenomena. The specific objective of this second article is to illustrate how these changes in the climate system will manifest as changes in land and vegetation cover, cryospheric states, and hydrological cycling.

The article is organized as follows: Sect. 2 provides a brief overview of CCRN's geographic domain and the two major river basins. Section 3 examines a number of different cold-region processes, their interactions and responses to climate, and their influence on water cycling. This highlights complexities that most Earth system models fail to capture. Section 4 briefly describes the advancements in fine-scale and large-scale process-based hydrological models during CCRN, along with their application for the diagnosis and prediction of change, while Sect. 5 provides a synthesis of this change over the CCRN region for the 21 st century. Section 6 provides concluding remarks and identifies knowledge gaps for further research.

\section{Ecological regions and river systems of the interior of western Canada}

The interior of western Canada spans a wide range of climatic, ecological, and physiographic regions (Fig. 1) and has many of the physical attributes common to cold regions worldwide (Woo et al., 2008). This includes extensive areas of permafrost and seasonally frozen ground, snow, and ice cover through a large part of the year and water cycling that is driven largely by seasonal patterns of energy availability. The principal river systems include the Saskatchewan and Mackenzie Rivers and their respective $406000 \mathrm{~km}^{2}$ and 1.8 million $\mathrm{km}^{2}$ drainage basins (Fig. 1). These encompass Prairie, Boreal (including Taiga), Tundra, and Cordillera landscapes (CEC, 1997).

The Saskatchewan River originates in the Rocky Mountains of Alberta and Montana and flows through the province of Saskatchewan and into Manitoba, discharging into Lake Winnipeg. Most of the flow originates in the mountains, which provide roughly $80 \%$ of the total discharge (Pomeroy et al., 2005). The basin is mostly situated within the Prairies, a key agricultural region, and the Boreal Plain; the transition between these ecological regions is dynamic and largely coincides with an annual water balance threshold where $P$ equals potential evapotranspiration (PET), with a moisture surplus to the north and a deficit to the south (Ireson et al., 2015). In the southern and central portions of the basin, part of the Palliser Triangle, the climate is among the most arid in Canada, with annual $P$ as low as $350 \mathrm{~mm}$ or less (Szeto, 2007; Roussin and Binyamin, 2018). The landscape is mostly post-glacial topography, with large numbers of small depres- 

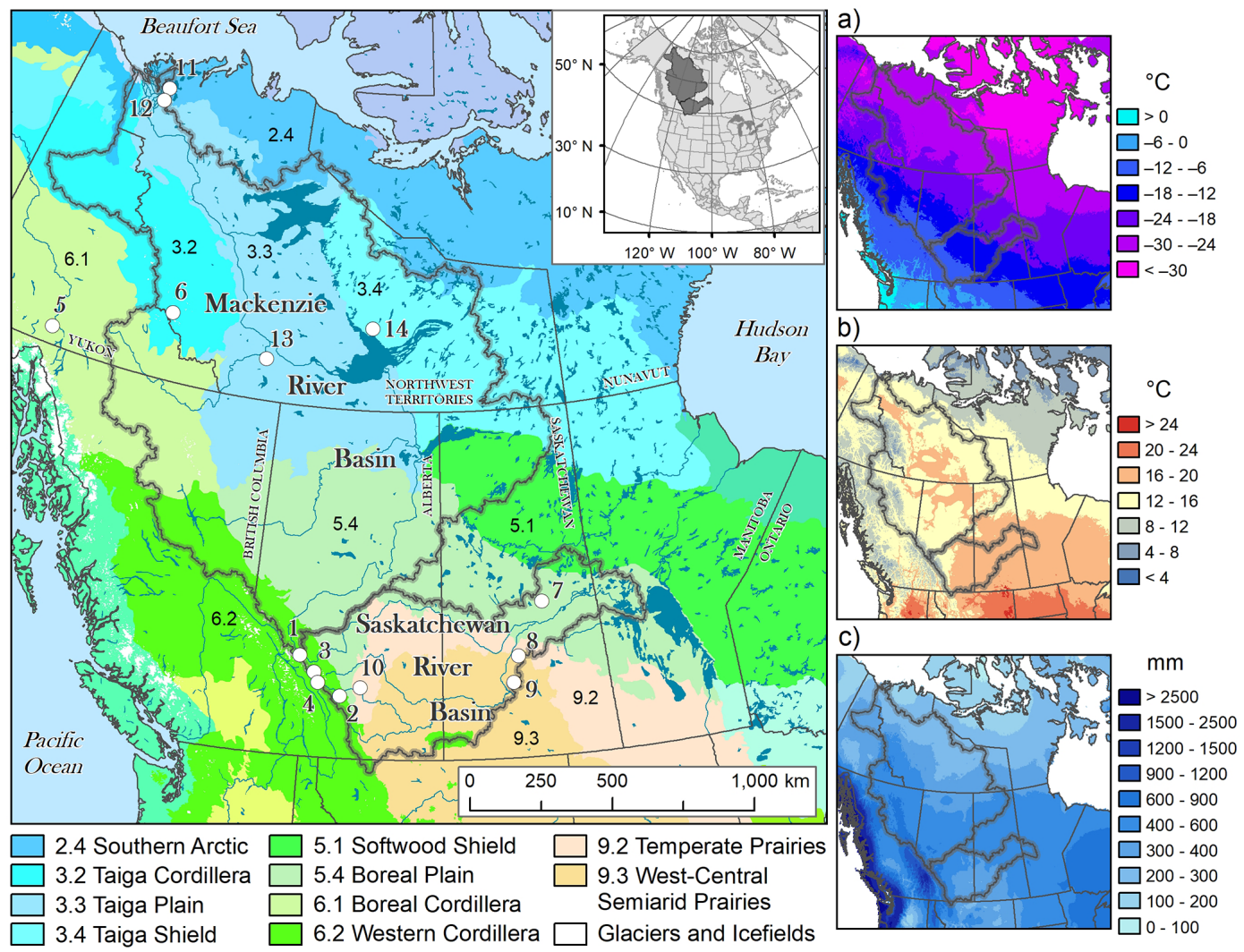

Figure 1. Map of the CCRN study domain across the interior of western Canada. The Mackenzie and Saskatchewan River Basins are shown and their location within North America is indicated in the inset map. Land cover and physiography are depicted by the Level II Ecological Regions of North America, with the naming convention and symbology of CEC (1997). The panels on the right show (a) January mean air temperature, (b) July mean air temperature, and (c) annual total precipitation. The locations of CCRN Water, Ecosystem, Cryosphere, and Climate (WECC) observatories are indicated by circles: (1) Columbia Icefield, (2) Marmot Creek, (3) Peyto Glacier, (4) Lake O’Hara, (5) Wolf Creek, (6) Brintnell-Bologna Icefield, (7) Boreal Ecosystem Research and Monitoring Sites (BERMS), (8) St. Denis National Wildlife Area, (9) Brightwater Creek/Kenaston Mesonet Site, (10) West Nose Creek, (11) Trail Valley Creek, (12) Havikpak Creek, (13) Scotty Creek, (14) Baker Creek. Source data are from the North American Environmental Atlas (http://www.cec.org/north-american-environmental-atlas/, last access: 6 April 2021), the National Hydro Network (http://www.geobase.ca, last access: 6 April 2021), WorldClim Global Climate Data (http://worldclim.org/version2, last access: 6 April 2021), and the Commission for Environmental Cooperation (http://www.cec.org, last access: 6 April 2021).

sions and poorly developed and internally drained stream networks (Pomeroy et al., 2005; Martz et al., 2007). Approximately $40 \%-50 \%$ of the basin does not contribute to river flows, with large-scale connectivity only developing in exceptionally wet conditions, and only a very small percentage $(\sim 1 \%)$ of the flow in the main river originates within Saskatchewan (Martz et al., 2007). The Prairie climate leads to large variability in local water flows and storages, as for example seen in the extreme drought of 1999-2004 (Hanesiak et al., 2011) and the high water levels and floods of the following decade (Dumanski et al., 2015; Szeto et al., 2015). Numerous environmental, societal, and management challenges exist in the Saskatchewan River Basin (Wheater and Gober, 2013; Gober and Wheater, 2014), and the South Saskatchewan River has been described as Canada's most threatened river (WWF, 2009). Irrigation is the dominant consumptive use of water, and despite Canada's reputation as a water-rich country, water resources are fully allocated in southern Alberta. Dam storage and hydropower development have caused major changes in the seasonal flow regime, impacting the habitats of the $10000 \mathrm{~km}^{2}$ Saskatchewan Delta, located at the Saskatchewan-Manitoba border.

The Mackenzie River drains about $20 \%$ of the Canadian land mass, spanning parts of British Columbia, Alberta, Saskatchewan, and the Yukon and Northwest Territories, and is the single largest North American source of freshwater to the Arctic Ocean (Stewart et al., 1998; Rouse et al., 2003; Woo et al., 2008; WWF, 2009). The Mackenzie River has a number of major tributary rivers, including the Athabasca, Peace, and Liard Rivers, as well as other smaller tributaries; overall, mountainous western parts of the basin collectively provide about $60 \%$ of the total flow (Woo et al., 2008). There 
are three major deltas: the Peace-Athabasca, the Slave, and the Mackenzie, which host diverse ecosystems. The basin covers large areas of Boreal and Taiga Forest, with relatively low relief and underlain by glacial plains in the south and southwest and by the Precambrian Shield with slightly more undulating topography in the east (Woo and Rouse, 2008). Much of the central and northern part of the basin is underlain by discontinuous and continuous permafrost, which is thawing at an accelerating rate (Burn and Kokelj, 2009; Baltzer et al., 2014). In the plains region, the basin includes several very large lakes, and a large portion of the area is covered by smaller lakes and wetlands (Woo et al., 2008). Climate conditions are cool, with considerable intra- and inter-annual variability in air temperature, and the region is a source area for cold, continental air masses (Szeto et al., 2008). The basin is a globally important resource that affects the welfare of people throughout the Western Hemisphere and globally, yet the ecological, hydrological, and climatological regimes are changing rapidly and are threatened by global warming and human impacts (RIFWP, 2013). While the majority of the river basin is largely undisturbed, local impacts on river flows and ecosystems arise in the headwaters due to operation of the Bennett Dam on the Peace River, and in downstream areas, for instance, due to operations of the Athabasca oil sands.

Over this region, past changes in stream and river discharge have exhibited a trend towards earlier spring freshet and river ice breakup and an increase in winter discharge in many northern basins (DeBeer et al., 2016). Other changes have included increasing importance of rainfall in generating flood events (Dumanski et al., 2015; Burn and Whitfield, 2016), a shift in flood regime along the continuum from snowmelt to more mixed and rainfall-driven regimes (Burn and Whitfield, 2018), and, in spite of warming spring air temperatures, delayed spring streamflow in some areas of the southern Arctic (Shi et al., 2015). Naturalized flows (after accounting for the changes due to reservoir operations and water withdrawals) of the South Saskatchewan River have exhibited a steady decline since the early 20th century, with late summer volumes declining at a greater rate than the annual discharge (Pomeroy et al., 2009). Flows in the Mackenzie River since the early 1970s have shown a shift in timing of peak flows of several days, an increase in maximum discharge of about $3000 \mathrm{~m}^{3} \mathrm{~s}^{-1}$, and a rise in winter base flows (Yang et al., 2015).

\section{Process interactions, changes, and their influence on water cycling}

Field-based observations and experimentation across the network of WECC observatories (Fig. 1) and at other sites have provided key insights into process interactions and responses. Here we summarize these insights for several important hydrological and ecological processes.

\subsection{Precipitation recycling and evapotranspiration}

$P$ and evapotranspiration (ET) are important terms in the water cycle, and even minor shifts in their relative magnitudes can have critical impacts on surface water availability, streamflow, and groundwater storage. Recent changes in $P$ over western Canada have shown regional and seasonal variations, with annual and winter increases in volume in the north and more significant winter decreases in the southern interior (Vincent et al., 2015; DeBeer et al., 2016). Pervasive warming has led to notable declines in the fraction of winter $P$ falling as snow (Vincent et al., 2015; Dumanski et al., 2015). Historical variations and patterns of ET in western Canada have shown mixed trends, in part, due to the challenges with measurement, data availability, and modelling of ET (Mortsch et al., 2015). ET is affected by many variables, including precipitation, air temperature, surface and soil moisture availability, net radiation, wind speed, humidity, and vegetation characteristics. Thus, it is spatially highly variable over heterogeneous landscapes and is sensitive to changing climate and to land cover change (Zha et al., 2010). Changes in $P$ amount and character are controlled to a considerable degree by global- and continental-scale conditions and their influence on regional circulation, air mass characteristics, and smaller-scale variability. These changes are presented and discussed by Stewart et al. (2019). Some further consideration of interactions at the surface and landatmosphere feedbacks that affect local $P$ processes is presented here.

Regional moisture recycling between $P$ and ET is prevalent and provides a significant portion of the warm-season $P$ across much of the Saskatchewan and Mackenzie River Basins (Szeto, 2007; Szeto et al., 2008). It represents an important mechanism of moisture transport, in some instances leading to intense rainfall and flooding (Li et al., 2017), and may have an important role in sustaining wet (or dry) conditions on seasonal to inter-annual timescales. For example, there are important feedbacks between ET and $P$, where an increase in $P$ is likely to increase ET, but the increase in $P$ itself could also be a result of increasing land ET and stronger moisture recycling (Trenberth, 1999; Dirmeyer et al., 2009). In future, under a warming climate, earlier disappearance of the seasonal snow cover will act to increase regional ET in spring as a result of the reduction in surface albedo, increase in net radiation to the ground surface, increase in overall surface temperature, thaw of frozen ground, and increase in exposure of wet soils. Shorter ice cover duration, especially in more northern lakes, will lead to increased lake evaporation and will therefore also play an important role in providing local moisture sources to downwind regions. These effects, together with earlier onset of ET from vegetation as a result of changes in the timing of leaf emergence, will enhance local atmospheric moisture supply in spring, possibly further enhancing the projected increase in March-April-May $P$ (see Fig. 5 of Stewart et al., 2019). Later freeze-up in the fall can 
have similar effects, producing more lake effect snowfall, for example.

Kurkute et al. (2020) simulated future changes in $P$ and ET over the Saskatchewan and Mackenzie River Basins using a pseudo global warming (PGW) approach with a highresolution $(4 \mathrm{~km})$ Weather Research and Forecasting (WRF) model (Li et al., 2019). Under the Representative Concentration Pathway $8.5 \mathrm{~W} \mathrm{~m}^{-2}$ (RCP8.5) radiative forcing scenario, their results show increases in $P$, ET, and moisture recycling in both basins for the late 21 st century (2085-2100) relative to their control period (2000-2015) but with considerable seasonal and spatial variations (Fig. 2). In the early spring (March and April), increases in $P$ are projected to exceed increases in ET, leading to increasing snowpacks and/or soil moisture, but by May, the earlier snowmelt and increased atmospheric evaporative demand lead to greater increases in ET compared to $P$ and drying of soils over much of the Prairies and Boreal Forest of western Canada (see Figs. 9 and 10 of Kurkute et al., 2020). This pattern continues into summer, and by July and August, simulated future $P$ decreases in these parts of the region (most of the Saskatchewan River Basin), due in part to the decrease in soil moisture and surface water availability in the antecedent spring months. Although there is a simulated increase in moisture recycling in the warm season, the excess of ET over $P$ is associated with an increase in atmospheric moisture divergence (i.e., transport out of the region).

Changes in ET also occur as a consequence of land cover and vegetation changes. Vegetation cover in turn is influenced by soil moisture (which is controlled by topographic position and surficial geology) but also by disturbance and succession dynamics (Ireson et al., 2015). The main vegetative controls on ET include leaf and canopy characteristics (vegetation height, LAI, leaf shape, stomatal behavior) and rooting depth and dynamics (Zha et al., 2010; Black and Jassal, 2016; Nazarbakhsh et al., 2020). Margolis and Ryan (1997) showed that, due to physiological limitations to transpiration in Boreal needleleaf trees, they have much lower ET rates than deciduous species, even when soil water is abundant. This is consistent with observations at the Boreal Ecosystem Research and Monitoring Sites (BERMS) flux towers (Fig. 1, site 7), showing a mature aspen stand with higher ET than a mature black spruce, which had higher ET than a jack pine stand (Fig. 3). Kljun et al. (2006) attributed these differences to a combination of type of tree species, topography, and soil type. Very young forest stands have also been shown to have much lower rates of ET than older stands (Granger and Pomeroy, 1997). Thus, shifts in Boreal Forest composition and structure, from coniferous to deciduous or mixed wood, or from black spruce to jack pine (discussed in Sect. 3.4 below), will have potentially large but speciesspecific effects on regional ET.

In the northern parts of the CCRN region, thaw-induced landscape change (Sect. 3.5) and expansion of shrubs (Sect. 3.4) are among the key drivers of changes in ET. In- creasing thaw depth and shrinkage of permafrost-underlain areas impact growth and physiological processes of the trees through drying of the rooting zone, driving decreases in the productivity of black spruce-dominated sub-Arctic forests and reduction of sap flow and ET (Patankar et al., 2015; Sniderhan and Baltzer, 2016). At the same time, however, the conversion from forest to wetland associated with permafrost thaw acts to expand areas of open, freely evaporating water surfaces, counteracting this effect (e.g., Carpino et al., 2018). Warren et al. (2018) demonstrated that at Scotty Creek (Fig. 1, site 13), ET attributable to black spruce accounted for less than $1 \%$ of landscape ET, suggesting areas of open water are of much greater importance to the water balance regionally. The expansion of shrubs in northern tree line and Tundra environments will likely increase regional ET in the snowfree period. For example, Zwieback et al. (2019b) found that rainfall interception losses from birch shrubs at Trail Valley Creek in the southern Arctic (Fig. 1, site 11) reduced below-canopy rainfall by $15 \%-30 \%$ but that losses depend on shrub species and density. Shrubs can efficiently reduce stomatal conductance under conditions of high vapor pressure deficit and their shading effect can act to limit surface evaporation under dense shrubs (Lund, 2018), further complicating the responses to shrub expansion. Shrub-snow interactions (Sect. 3.2) essentially act to retain winter snowfall and increase post-melt water availability, resulting in greater ET (Pomeroy et al., 2006; Ménard et al., 2014).

\subsection{Snow regime change and snow-vegetation interactions}

Over western Canada during the past several decades there has been a widespread reduction in snow depth, snow cover extent, and seasonal duration, with a shorter snow cover period of between 1 and 2 months, mostly due to earlier melt in spring (Brown et al., 2010, 2020; Mudryk et al., 2018; Marsh et al., 2019). Projected climate warming over the coming decades will continue to cause ubiquitous changes in snow regime, including (i) a greater fraction of $P$ in the form of rain as opposed to snowfall, especially during shoulder seasons, at lower elevations, and in more southerly locations, (ii) more frequent rain-on-snow events, (iii) warmer and wetter snowfall, (iv) more mid-winter melt events as air temperature crosses the freezing point more frequently, and (v) earlier spring melt and snow cover depletion (Fig. 4). This will also cause distinct changes in runoff, with further transition from snowmelt to rainfall-dominated regimes. The transitions from snowfall to rain and from snow-dominated to rain-dominated hydrological systems are particularly sensitive where and when conditions are relatively warm and large amounts of $P$ occur near $0{ }^{\circ} \mathrm{C}$ (Mekis et al., 2020). For example, analysis by Harder and Pomeroy (2014) in the Rocky Mountain Front Ranges at Marmot Creek (Fig. 1; site 2) showed that a significant proportion of the observed $P$ events, recorded as either snowfall or rain, occurred within 
Saskatchewan River Basin
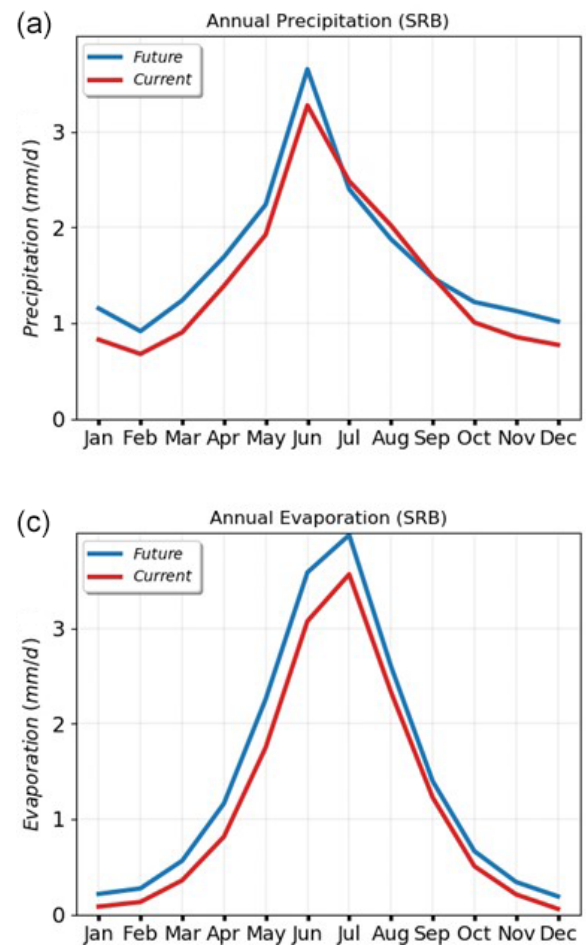

Mackenzie River Basin
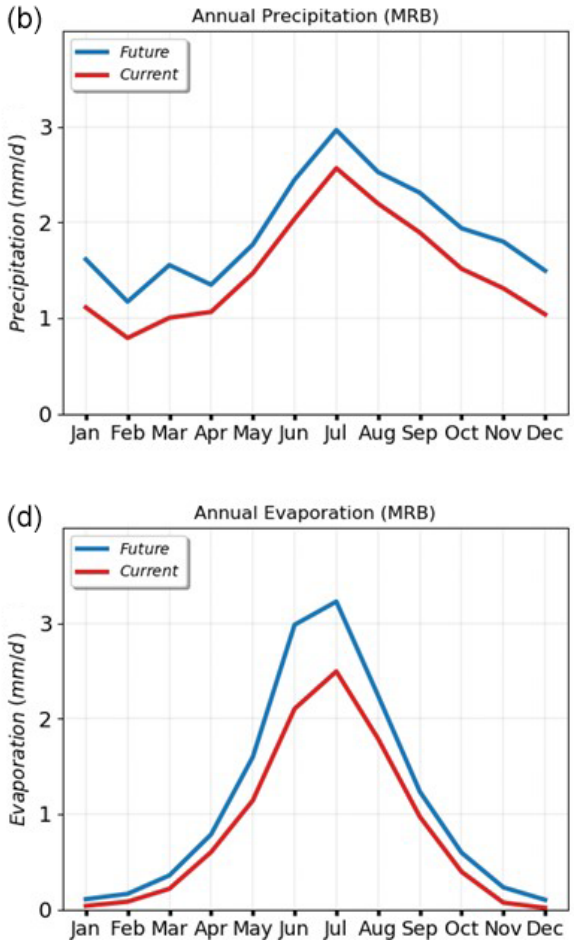

Figure 2. Simulated $P$ and ET surface water budget components $\left(\mathrm{mm} \mathrm{d}^{-1}\right)$ over the Saskatchewan (a, c) and Mackenzie (b, d) River Basins for the WRF control (current; 2000-2015) and future (2085-2100) periods. Results are from Kurkute et al. (2020).

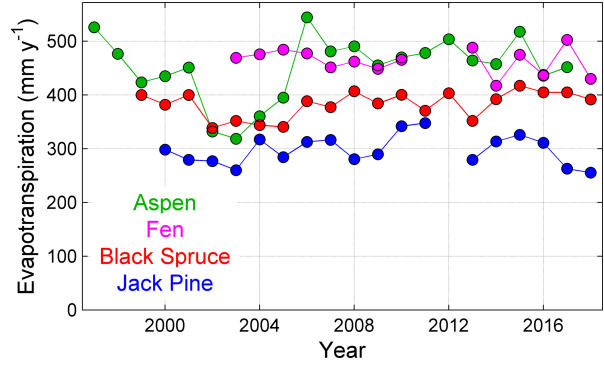

Figure 3. Annual ET (with energy-balance-closure adjustments) at the four BERMS sites from 1997 to 2018 showing generally higher values for the Old Aspen site than for the two conifer sites. The dry conifer site (Old Jack Pine) generally had lower ET than the wet conifer site (Old Black Spruce). The Fen had values exceeding the Old Aspen site following the 2001-2003 drought, with similar values in other years.

just a few degrees plus or minus of $0{ }^{\circ} \mathrm{C}$ as air temperature or hydrometeor temperature. Even slight warming could lead to rain becoming dominant at such locations. Shi et al. (2015) described the effects of increased rainfall during the snowmelt runoff period at Trail Valley Creek.

Hillslope-scale snowmelt runoff is potentially highly vulnerable to warming temperatures and associated changes in the amount and phase of precipitation. For instance, at three small (5 ha) hillslopes in the Saskatchewan Prairie, Coles et al. (2017) found that increases in summer rains were buffered by the unfrozen, deep, high-infiltrability soils. In contrast, winter and spring melt onto frozen ground with limited soil infiltrability resulted in runoff responses that more closely mirrored the snowfall and snowmelt trends. Increasing occurrence of mid-winter melt events can also alter the timing and magnitude of depression-focused groundwater recharge (Pavlovskii et al., 2019) and may lead to more basal ice formation, producing complex runoff responses in spring. Follow-on hillslope-scale analysis by Coles and McDonnell (2018) found evidence for filling of micro- and mesodepressions on the slope, followed by macro-scale, wholeslope spilling. While surface topography is relatively unimportant under unfrozen conditions on low relief and high infiltrability Prairie sites, surface topography was of critical importance for connectivity and runoff generation when the ground was frozen during the brief, annual snowmelt pulse. Under climate warming, losing this brief period of surface topographic control on runoff generation could have large implications for hillslope runoff, depending on basal ice formation, among other factors.

Warming can also lead to other important, and sometimes unanticipated, responses in snow accumulation, redistribution, and ablation processes (Fig. 4). Earlier onset of spring melt of the seasonal snow cover shifts snowmelt timing to 
(a) Climate interactions
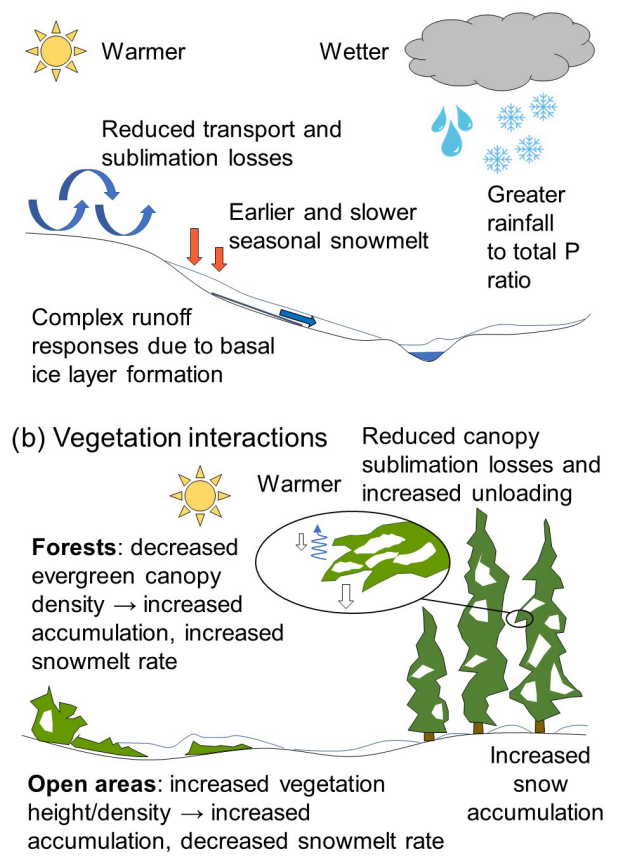

Figure 4. Conceptual schematic of expected snow change in the CCRN domain and similar cold regions. Warmer conditions lead to less snow, while wetter conditions can lead to more or less snow; warmer and wetter conditions can be partially compensatory. Other changes complicate the snow-climate interactions, and spatial patterns of vegetation change with respect to snow processes control snow response.

conditions of lower incoming solar radiation (Pavlovskii et al., 2019). Paradoxically, this can lead in some cases to a reduction in daily and seasonal average ablation rates and a longer overall period of melt (Pomeroy et al., 2015; Musselman et al., 2017), but not in the Arctic, where both earlier and faster overall melts are predicted (Krogh and Pomeroy, 2019). This is counterintuitive and would not be captured by simple temperature-index melt models (Pomeroy et al., 2015). Warmer and wetter snow has lower susceptibility to wind transport (Li and Pomeroy, 1997), leading to a potential reduction in blowing snow transport and sublimation losses, which can partially offset reductions in snow water equivalent (SWE) due to direct effects of climate warming. Model results by Pomeroy et al. (2015) at Marmot Creek indicate a reduction of blowing snow transport by up to $50 \%$ and decrease in sublimation losses by up to roughly $30 \%$ with warming of up to $5^{\circ} \mathrm{C}$. This would also have important but at present poorly understood consequences for the redistribution of snow, the variability and patterns of SWE over the landscape, and the timing and rate of snow cover depletion (e.g., DeBeer and Pomeroy, 2017). Suppression of blowing snow would lead to a more uniform spatial distribution and thus more rapid decline of snow-covered area that could not be compensated for by the variability in melt energy (Schirmer and Pomeroy, 2020).

Snow-vegetation interactions further affect hydrological responses, and the impacts of vegetation change can equal or exceed those due to climate alone (Rasouli et al., 2019). A conceptual summary is shown in Fig. 4. With rising temperatures, warmer and wetter intercepted snow is more likely to fall to the ground instead of remaining in the forest canopy, where it would otherwise mostly sublimate. Snowfall interception efficiency is relatively insensitive to air temperature (Hedstrom and Pomeroy, 1998) and thus warming is unlikely to lead to large changes in initial interception amounts. But retention of the intercepted snow load is highly temperature dependent (Ellis et al., 2010) and so warming promotes faster unloading and a lower sublimation loss. This acts in combination with reduced wind transport of snow on the ground to offset reductions in SWE due to direct warming effects (Pomeroy et al., 2015). Rising temperatures can shift sub-canopy snowmelt energetics such that the reduction in melt rates due to shading is overcome by the increase in melt due to enhanced long-wave radiation from the canopy (Lundquist et al., 2013). Forest canopy structure, density, and species composition also significantly influence interception loss. Thinning of existing forest cover, reduction in leaf area index (LAI), and transition from coniferous to deciduous species, which are expected as a result of increasing human and natural disturbance and wildfire (Sect. 3.4), will lead to greater surface snow accumulation due to the reduction in canopy interception and sublimation but at the same time will expose more of the snow surface to increasing net radiation and an accompanying increase in ablation rates.

In open, windswept environments dominated by short vegetation such as grasses, crops, and shrubs, expansion across the landscape and/or increasing height and density of vegetation influences surface water availability and landatmosphere energy and moisture exchanges. Shrub expansion acts to enhance local snow accumulation through more trapping of wind-blown snow and suppression of blowing snow redistribution and sublimation (Pomeroy et al., 2006; Ménard et al., 2014; Wallace and Baltzer, 2019). Shrubs reduce albedo in the spring but are buried in winter and have little effect on albedo in summer. Their canopy reduces latent heat fluxes from snow in the spring and initially accelerates melt when partly exposed and then retards snowmelt when the shrub canopy is fully exposed (Pomeroy et al., 2006; Wilcox et al., 2019). In the Prairies, increasing crop stubble height acts to retain more snow and to increase melt rates, infiltration, and meltwater runoff (Harder et al., 2019).

\subsection{Glacier loss}

In western Canada and globally, glaciers have been predominantly losing mass and retreating in extent, with an apparent acceleration in their wastage in recent decades (Demuth et al., 2008; Demuth, 2018; Menounos et al., 2019; DeBeer 
et al., 2020). Even in the absence of further warming, many of these glaciers are out of balance with the current climate, given their present configuration (Zemp et al., 2015; Marzeion et al., 2018). This indicates that they will further recede to adjust their geometry to the current climate, with a typical response time of several decades for glaciers in western Canada (Marshall et al., 2011; Marzeion et al., 2018). Ongoing climate change is expected to further exacerbate the current imbalance and lead to additional retreat (Clarke et al., 2015).

Mass balance (the net gain or loss of snow and ice averaged over the glacier surface) responds directly to climate perturbations, whereas glacier extent, form, and flow patterns exhibit delayed and modified responses to mass balance changes (Cuffey and Paterson, 2010). Glacier responses are also influenced by secondary factors such as temperature effects on ice flow and meltwater availability at the glacier bed, which affects glacier sliding. In general, warmer air temperatures lead to greater specific ablation rates and a longer melt season, and may reduce accumulation depending on the area-elevation distribution of individual glaciers and the nature of $P$ changes. Many glaciers and icefields in the CCRN region receive snowfall year round at high elevations and some rainfall in the summer. With climate warming, the proportion of rainfall events increases and the late summer snowline moves to higher reaches of the glaciers, exposing firn and bare ice, which melt faster than snow due to their lower albedo. Dust, impurities, and algae in the snow and ice become more concentrated on glacier surfaces as a consequence of high melt rates, in turn reducing the albedo and further enhancing melt (Williamson et al., 2019; DeBeer et al., 2020). There may also be an interaction with wildfire in western Canada, with deposition of black carbon and forest-fire fallout further reducing glacier albedo and providing nutrients to microbial communities (e.g., Marshall and Miller, 2020). High thinning rates in the upper accumulation area of many glaciers in western Canada indicate that these processes are well under way (Anderson, 2017; Pelto et al., 2019; Ednie and Demuth, 2018), while reductions in accumulation zone extent can lead to rapid glacier disintegration, and even complete disappearance. Glacier fragmentation and detachment of tributary ice streams leads to loss of ice supply to lower reaches, which can then become stagnant and melt out.

There are other important glacier-climate feedbacks. Energy balance conditions shift in response to glacier retreat; for example, ice-free marginal areas and valley walls contribute turbulent energy supply and long-wave radiation fluxes to the glacier, and these fluxes can be enhanced as glaciers thin and retreat, increasing ablation rates. The presence of glacial ice helps to regulate local climates and preserve cold conditions. As reduced snow accumulation leads to a reduction in glacier mass balance, so a reduction in glacier extent leads to a reduction in snow accumulation, given that the glacier surface, which is $\leq 0^{\circ} \mathrm{C}$, helps retain snow cover (Marshall et al., 2011).

Projections of future glacier change indicate that glaciers in the Rocky Mountains will lose roughly half their total area and volume by mid century, regardless of RCP scenario, and from about $75 \%$ to $95 \%$ or more by the end of the 21 st century under the RCP2.6 to RCP8.5 scenarios, respectively (Clarke et al., 2015). By mid century, many valley glaciers will have retreated substantially up-valley, and by late in the century even high elevation glaciers and icefield plateaus will be greatly reduced or will have disappeared entirely (Fig. 5). Even the Columbia Icefield (see Demuth and Horne, 2017, and Tennant and Menounos, 2013), the largest and among the highest elevation ice masses in the Rocky Mountains, is projected to disintegrate into several small vestigial patches of ice near the tops of the highest peaks by the late 21st century. There are no comparable studies for the glaciated regions of the Mackenzie Mountains, Northwest Territories, but the observed patterns of recent change are similar to glaciers in the Rockies and the future change is expected to be similar (Demuth et al., 2014; Ednie and Demuth, 2018).

From a hydrological perspective, as glacier loss progresses, glacier wastage contributions and enhanced ablation will increase glacial contributions to discharge towards "peak water" (Huss and Hock, 2018), followed by a decline in glacier runoff due to loss of ice-covered area, even with further warming and increasing specific ablation rates. It remains uncertain where, when, and over what scales this will occur, although some studies have indicated that peak water has already passed in parts of southwestern Canada (Moore et al., 2020). Clarke et al. (2015) projected that peak runoff of glacier meltwater will occur between 2020 and 2040. Projections of glacier decline on the eastern slopes of the Rocky Mountains by Marshall et al. (2011) indicate a substantial decline in glacier contributions to discharge from about $1.1 \mathrm{~km}^{3} \mathrm{yr}^{-1}$ early this century to $0.1 \mathrm{~km}^{3} \mathrm{yr}^{-1}$ by late in the 21st century. With the loss of glaciers, the buffering effect that glacial storage can provide for discharge variations (e.g., during drought years) in the mountain headwaters will become increasingly diminished (Demuth and Ednie, 2016).

\subsection{Northern vegetation, wildfire, and loss of ecological resilience}

Ecosystem change can have profound effects on hydrological response and land-atmosphere feedbacks, yet the complexity of expected change and the associated uncertainty are often overlooked in hydrological projections. Across the CCRN region, contemporary climate change is already having direct impacts on northern ecosystems, defined here as including the southern Boreal Forest and its transition with the Prairies and the Cordillera. The interior of western Canada has been identified as a region of maximum ecological sensitivity (Bergengren et al., 2011). Forests in the southern Boreal region of western Canada have shown signs of declining pro- 

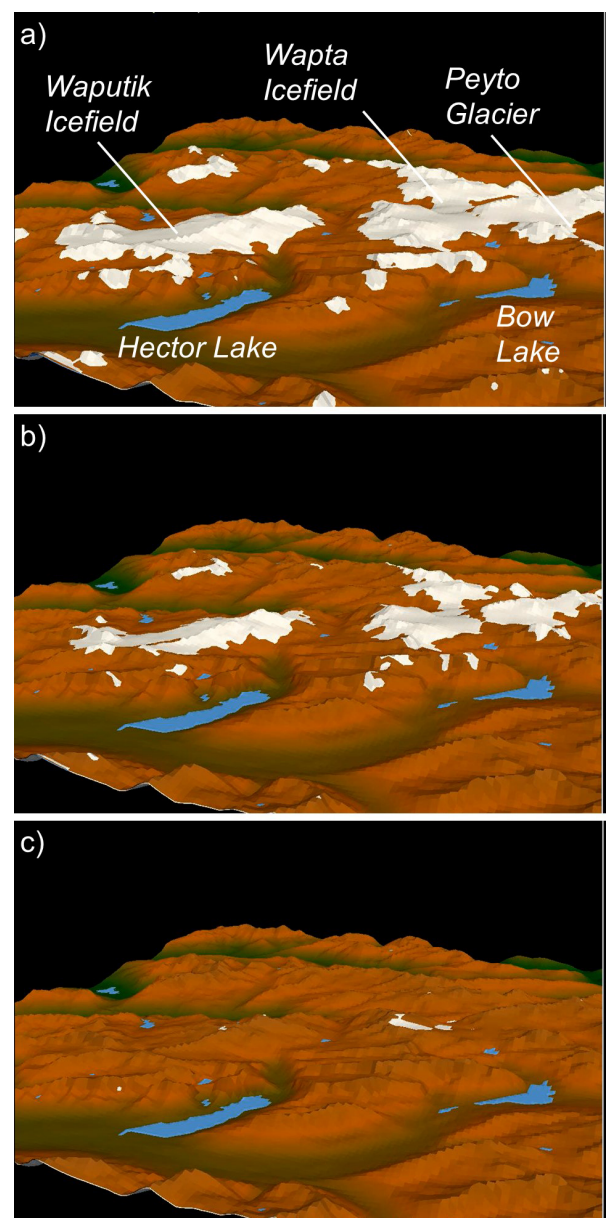

Figure 5. Simulated glacier projections in $3 \mathrm{D}$ perspective along the continental divide and in the headwaters of the Saskatchewan River for (a) 2005, (b) 2040, and (c) 2085 using the Canadian Earth System Model under the RCP8.5 forcing scenario. Scale varies in the perspective, but the ground distance across the length of the Waputik Icefield in the 2005 scene is roughly $12 \mathrm{~km}$. Results are from Clarke et al. (2015).

ductivity and increasing mortality associated with drought stress or insect disturbances, including widespread dieback and mortality of aspen (Hogg et al., 2008), stand fragmentation, and increases in tree mortality of up to $2.5 \% \mathrm{yr}^{-1}$ (Peng et al., 2011). Farther north, remote sensing indices of vegetation greenness indicate that substantial areas of Tundra and northern Boreal Forest have been increasing in vegetation productivity (Ju and Masek, 2016; Keenan and Riley, 2018; Sulla-Menashe et al., 2018). This is largely due to expansion of woody shrubs, such as alders and tall willows (Myers-Smith et al., 2011, 2019; Lantz et al., 2013), infilling of forests near the northern tree line (Lantz et al., 2019), and increases in tree growth rates (Sniderhan et al., 2020). Advancement of the Taiga-Tundra tree line in response to recent trends of climate warming has been more variable (Harsch et al., 2009; Dearborn and Danby, 2018). Lantz et al. (2019) showed infilling of forests below the tree line in the Northwest Territories but no increase in tree density above the tree line in the Tundra. To the south in the Rocky Mountains, Trant et al. (2020) observed widespread upward advance in alpine tree lines and increases in tree density, with changes in growth form from krummholz to erect tree form.

Climate change alters terrestrial ecosystems broadly through changes to (1) composition (vegetation, soils, and wildlife), (2) configuration and disturbance patterns, and (3) function. This includes structural changes to the current vegetation (above- and below-ground biomass, plant density, canopy height, LAI, and rooting depth); changes to land cover distribution patterns (resulting from changes in the disturbance regime and changes in competition, colonization, ecosystem resilience and vegetation succession following disturbance); and functional changes (surface albedo, snow accumulation and melt, soil freeze and thaw, ET, ecosystem productivity, decomposition, biogeochemical cycling, and wildlife habitat). The direct climatic drivers of vegetation change include rising atmospheric $\mathrm{CO}_{2}$ concentrations and temperature- and moisture-induced shifts in plant community function and vegetation distributions. However, over the 21 st century the greatest impacts of climate change on vegetation dynamics are expected to be indirect, via increased frequency and intensity of disturbance (wildfire, insect outbreaks, and other landscape-scale disturbances; Turetsky et al., 2017) leading to losses of ecosystem resilience. These intensified disturbance processes can cause ecosystems to reach critical tipping points, triggering ecological state change (reviewed by Johnstone et al., 2016). Imposed on the climate-induced changes in vegetation will be the potential for changing human activities (e.g., logging, land clearing for agriculture and mining; Landhausser et al., 2010; Hannah et al., 2020), some of which will interact with climate change to accelerate vegetation change.

Northern ecosystems are expected to be most resilient to disturbances and environmental conditions that are within the historic range of variability and previous adaptation (Keane et al., 2009; Johnstone et al., 2016; Seidl et al., 2016). Many northern ecosystems may be initially resistant to change, because feedbacks associated with long-lived vegetation help to maintain environmental conditions and ecological functions that support ecological stability, even during directional environmental change (Chapin et al., 2004). While fire has been a foundational process in the functioning and ecology of the Boreal Forest for more than 5000 years, an increase in the frequency of high-intensity fires, coupled with a warming climate, may weaken ecosystem resilience and disrupt the historically stable cycles of forest succession. The result may be a regime shift from one plant community to another and from one stability domain to another (Johnstone et al., 2010c, 2016). Wildfire activity has increased in recent decades across the Boreal Forest (Hanes et al., 2019) and there are indications that fires are burning more severely (Turetsky et al., 2011) and deeper into stored legacy carbon 
(Walker et al., 2019), creating novel conditions for forest regeneration (Johnstone et al., 2010a; Pinno et al., 2013). For example, stands may burn at young ages before trees are old enough to generate seeds; these events, especially when they occur in combination with unusually dry or warm years, can trigger regeneration failures and cause shifts to non-forested states (Brown and Johnstone, 2012; Whitman et al., 2018). Stand-replacing wildfires initiate new phases of forest regeneration where seedlings may be much more sensitive to climate conditions than in an established stand where canopy trees substantially alter the local microclimate (Johnstone et al., 2010b; Davis et al., 2019; Hart et al., 2019). There is consensus that in northern forests, fire frequency and severity will continue to increase (Rogers et al., 2020).

Projections of future wildfire-induced ecosystem change in the Boreal Forest are challenging and highly uncertain. Increasing fire will result in a younger forest, widespread replacement of black spruce stands, and higher proportions of deciduous broadleaf species or jack pine (e.g., Johnstone et al., 2010a), with greater change in the south than the north. CCRN developed a plausible scenario of post-fire replacement of evergreen needleleaf forest (ENF) with deciduous broadleaf forest (DBF) across the Boreal Forest, as described in the Appendix, for the purpose of use in hydrological model future projections (Fig. 6). Although this is simply a scenario, and not a projection with an associated confidence level, the resulting forest change due to increasing wildfire is potentially great. For both the mid- and late-century periods, there is a considerable reduction in DBF across the southern parts of the Boreal Plain, as a result of increasing fire and the conversion of forest to grassland. Farther north and west, in the Taiga Plain, the Shield, and the Western Cordillera, there is extensive and progressive replacement of ENF with DBF as a result of both climate and fire-driven changes in forest succession. In reality, DBF and jack pine stands tend to be more resilient to fire (Hart et al., 2019), and less flammable in the case of DBF, and so their expansion may partially counter the increase in fire occurrence expected under a warmer climate.

Insects represent another form of disturbance with high potential for disrupting forest successional patterns, and may also lead to the replacement of black spruce stands by mixedwood and deciduous species (Pureswaran et al., 2015). Forest insects may expand northwards if warmer winter temperatures increase potential rates of population growth (Post et al., 2009; Bentz et al., 2010). For the first time, pest populations of mountain pine beetle have been found in the Northwest Territories (GNWT, 2013). Likewise, unusual outbreaks of spruce bark beetle in the Yukon and Alaska have been associated with warm winter temperatures that allow increased insect survival through the winter (Berg et al., 2006). In some cases, forests have exhibited high levels of resilience to new disturbance conditions, as in the rapid recovery to bark beetle outbreaks in the southwestern Yukon (Campbell et al., 2019).

Across the northern and alpine tree line and tundra areas, displacement of shrubs by ENF and larch forest will occur in areas where sparse forest cover exists (e.g., Mamet et al., 2019), while above the tree lines, shrub expansion into tundra environments will likely continue with warmer temperatures and increasing water availability. Large shifts in tree line position are not expected over the 21 st century due to both biological and geological constraints. At the northern tree line, the limited reproductive capacity of the tree species results in low seed availability, which restricts the rate of tree expansion into tundra ecosystems (Brown et al., 2019; Harsch et al., 2009), although this is dependent on the nature of the tree line, as expanded upon in Harsch et al. (2009). Similarly, the advance of the alpine tree line is restricted by geological and geomorphological controls such as avalanching, soil limitations, slope configurations that generate harsh winds, and other seed establishment and growth-limiting factors (Macias-Fauria and Johnson, 2013; Davis and Gedalof, 2018). Northern and montane shrub tundra areas will expand and continue the greening trend, with conversion of dwarfshrub and graminoid-dominated tundra to tall-shrub tundra, resulting in more and taller shrubs, and an increase in LAI for existing patches. At fine scales, the rate and location of shrub expansion are very heterogeneous due to combined moisture and nutrient-driven responses (Wallace and Baltzer, 2019). For instance, although most infilling and recruitment is expected to occur in valley bottoms, low-lying areas, and other locations with sufficient water availability, excess moisture can carry nutrients downslope. Shrub Tundra is also susceptible to disturbance-induced changes. Large fires can occur in Tundra environments (Mack et al., 2011), and increased fire activity may occur if temperatures cross climate thresholds that have regulated fire activity in the past (Young et al., 2017) or as fuel accumulates due to shrub expansion. Permafrost thaw also affects shrub colonization (see Sect. 3.5). Shrub expansion can have multi-directional hydrological impacts (Grünberg et al., 2020), including shrub-snow interactions (Sect. 3.2) and increasing ET (Sect. 3.1), warmer soils, greater thaw depth, and thermokarst and subsidence, altering supra-permafrost layer storage, flow paths, and lake development (Sect. 3.5).

In addition to the forest cover change scenario, CCRN developed a plausible scenario of 21 st century shrub expansion into Tundra, Grassland, and Barren areas, described in the Appendix and shown in Fig. 7. While there is uncertainty and this does not represent a confident projection, prolific shrub growth over the Boreal and Taiga Cordillera, the southern Arctic, and the Taiga Shield ecological regions is expected. The gradual expansion northward is evident through the increase in shrub cover along the northern part of the Mackenzie River Basin and the movement of this growth zone to higher latitudes later in the century. 

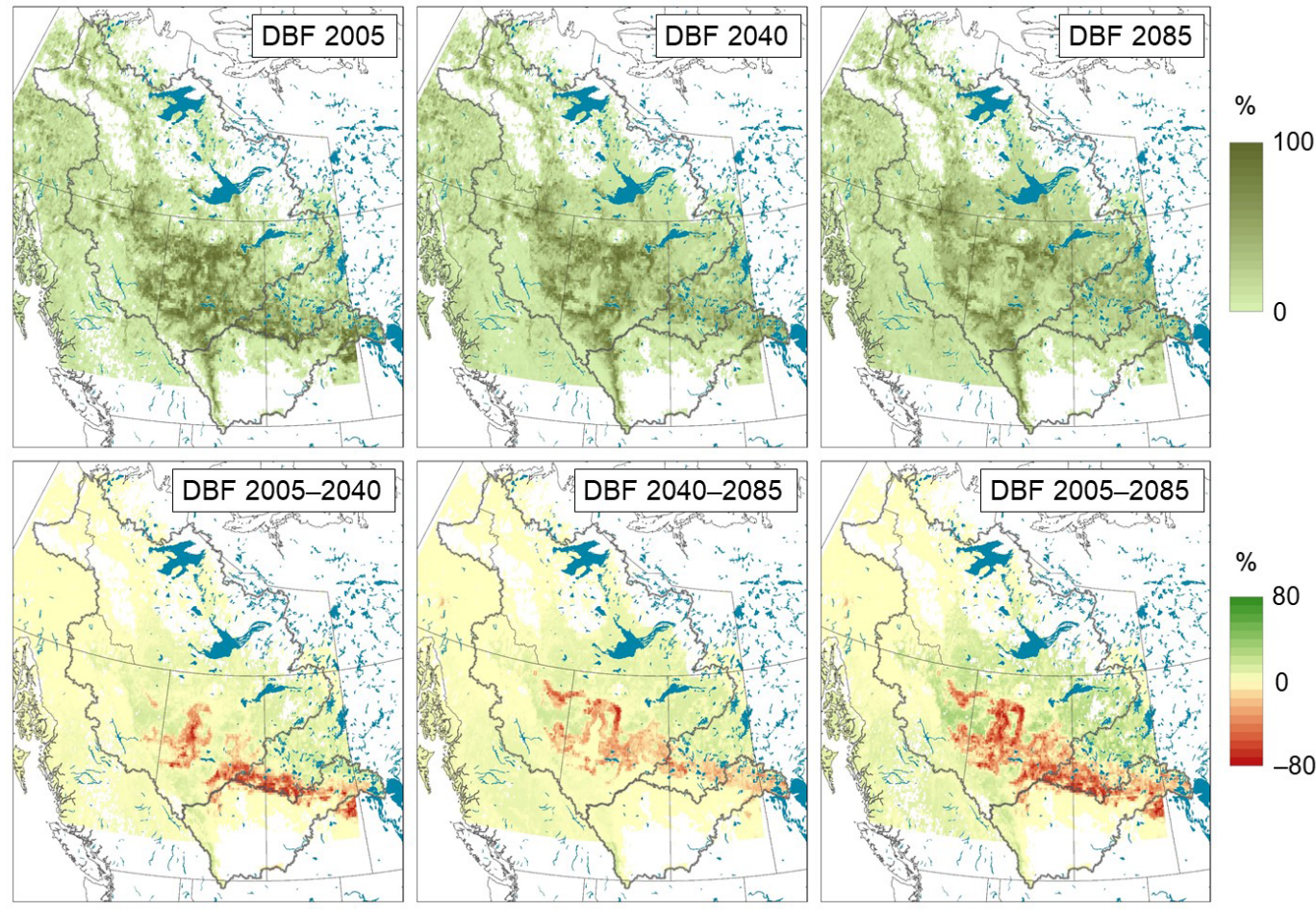

Figure 6. Changing DBF cover fractions over the Mackenzie and Saskatchewan River Basins in the 21st century. The approach involved a simple yet ecologically based projection with expert-guided modifications to impose restrictions on the rates of species colonization and requirements for wildfire to trigger change (Appendix). Projections were made in 45-year increments from the base period (centered at 1995 but using the 2005 base map) to represent the 2040 (mid-century) and 2085 (late-century) periods.

\subsection{Permafrost thaw as a driver of landscape change and hydrological rerouting}

Climate warming has led to warming and increased thaw depth of permafrost across northern Canada (Smith, 2011), with associated changes in characteristics of seasonally frozen soils (e.g., timing of freezing and thawing, frequency of freeze-thaw cycles, depth of frost). In southerly locations where permafrost is discontinuous, shallow, and relatively warm (i.e., at or near the freezing point depression), there has been widespread thawing and degradation of permafrost, with increasing supra-permafrost layer thickness - including both the active layer (seasonally frozen) and the talik (perennially thawed) (Connon et al., 2018). As a result of warming and shallower re-freeze depths during winter, active layer thickness has been decreasing. Where ice-rich soils occur, there has been active thermokarst development, slumping, and ground surface subsidence (Olefeldt et al., 2016; Turetsky et al., 2019). In permafrost lowlands of the Taiga Plain, soil thawing has led to subsidence and inundation of ground surfaces resulting in extensive forest loss, fragmentation, and concomitant wetland expansion and conversion mostly to sphagnum-dominated bogs (Baltzer et al., 2014; Helbig et al., 2016). In the southern Arctic, increased permafrost thawing is leading to changes in channel permafrost conditions, increasing winter groundwater flow in the channel, and increasing occurrence of aufeis formation (Ensom et al., 2020).

Many northern ecosystems are underlain by ice-rich permafrost that is highly sensitive to thawing during warm summers (Segal et al., 2016; Lewkowicz and Way, 2019) or following other disturbances (Williams et al., 2013). Wildfire and combustion of insulating moss and peat layers affects permafrost temperatures and can trigger thaw (Holloway et al., 2020). The lateral expansion of thermokarst features increases following wildfire activity; for example, Gibson et al. (2018) found that wildfire was estimated to be responsible for $30 \%$ of permafrost thaw expansion in the southern Northwest Territories. Some of the energy driving the thaw of permafrost enters the permafrost bodies laterally from adjacent permafrost-free terrains (Kurylyk et al., 2016). As such, the rate of permafrost thaw and forest loss is accelerating as patches of permafrost plateau become more fragmented, leading to greater proportional plateau edge to total plateau area (Quinton and Baltzer, 2013; Baltzer et al., 2014; Carpino et al., 2018). Reduced soil stability during thaw events can cause substantial mass wasting through thermokarst and retrogressive thaw slumps, with impacts on local vegetation and downstream drainage (Schuur and Mack, 2018). Once the vegetation is disturbed, colonization by tall shrubs can cause 


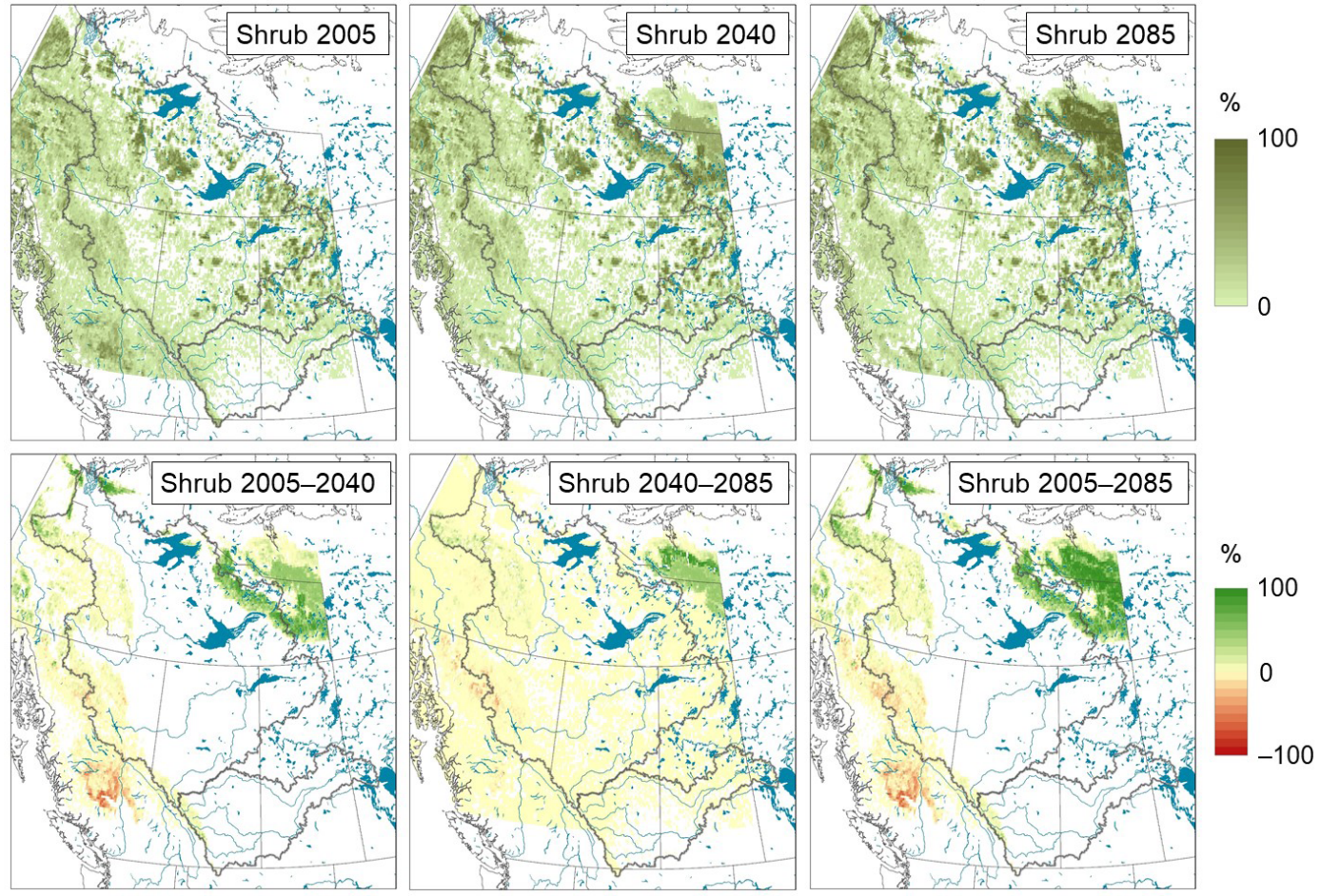

Figure 7. Changing shrub cover fractions over the Mackenzie and Saskatchewan River Basins in the 21 st century derived from CCRN expertguided modifications to climate-based projections using the methodology of Rehfeldt et al. (2012) (Appendix). Projections were made in 45-year increments from the base period (centered at 1995 but using the 2005 base map) to represent the 2040 (mid-century) and 2085 (late-century) periods.

a persistent change in vegetation state due to altered patterns of snow accumulation and soil temperatures (Lantz et al., 2009; Schuur and Mack, 2018).

Quinton et al. (2009) proposed a conceptual model of canopy thinning and permafrost thaw in which canopy thinning due to fire, disease, or other disturbance allows for an increase in local solar energy input and leads to preferential ground thaw (Fig. 8). A local depression forms in the relatively impermeable frost table and underlying permafrost table. Such thaw depressions introduce a hydraulic gradient that directs subsurface flow towards them so that thaw depressions soon become local areas of elevated soil moisture content. Since the thermal conductivity of wet soil is far more than that of dry soil, the vertical conduction of energy to the thaw depressions increases due to the increased moisture content, and as a result, a positive feedback is initiated, which accelerates the thaw of the disturbed areas. Wet conditions prevent trees from re-establishing and a new, isolated flat bog is formed. Many areas within the Taiga Plain are highly susceptible to thaw through this process (e.g., Gibson et al., 2020) and widespread replacement of forest-covered peat plateaus by wetlands is expected over the coming decades. A caveat is that these ecosystems represent some of the strongest ecosystem-protected permafrost, so undoubtedly a portion of permafrost peatland will linger, but this will depend on the degree of warming and also fire (Stralberg et al., 2020).

The loss of permafrost is impacting water cycling across the northern parts of the CCRN region. Land-surface subsidence and the collapse of peat plateaus to wetlands in the Taiga Plain alters drainage networks, surface and groundwater storage distribution, and the transit of water across the landscape (Fig. 8; Connon et al., 2014, 2018; Haynes et al., 2018; Quinton et al., 2019). This incorporates individual wetlands into the runoff contributing area, which expands deep into the interior of extensive plateau-wetland complexes as hydrological connections form between wetlands. The process results in both transient increases to basin discharge through the dewatering of incorporated wetlands, and longerterm increases in discharge arising from an expanded contributing area (Quinton et al., 2019). Another mechanism by which thaw influences runoff processes is by opening previously inaccessible subsurface flow pathways. Talik expansion provides an additional drainage path for wetland dewatering - one that conducts water throughout the year (Connon et al., 2018; Devoie et al., 2019). While this may give rise to transient increases in basin discharge due to the increased connectivity and dewatering of wetlands (Quinton et al., 2019), the process is not sustainable and may result in eventual drying of the landscape with increasing ET (Stone 


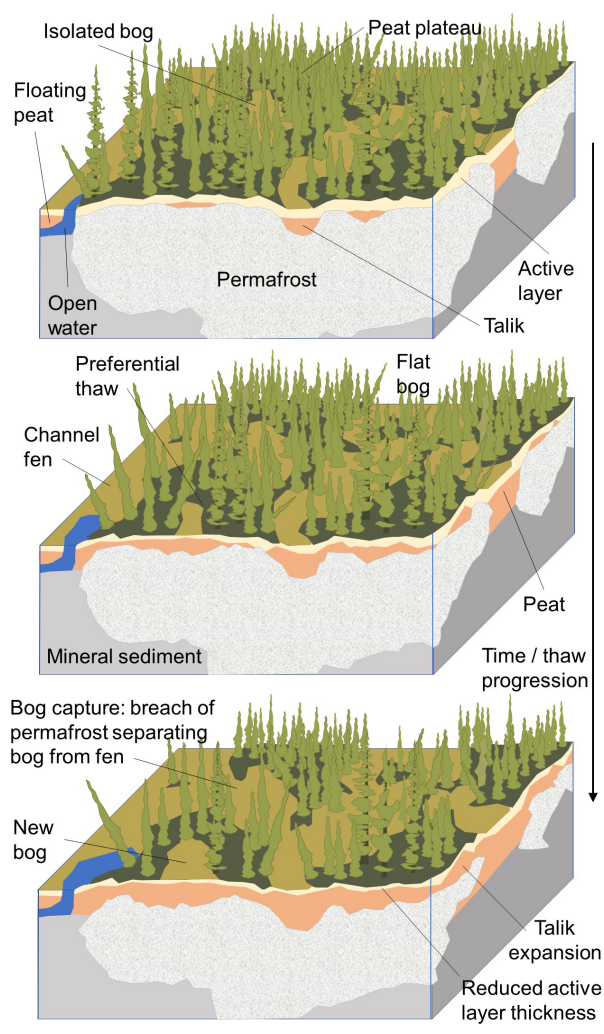

Figure 8. Conceptual model of forest canopy thinning and permafrost thaw in the Taiga Plain, after Quinton et al. (2009, 2019) and Connon et al. (2018).

et al., 2019). Regeneration of black spruce forest may ultimately occur in the absence of permafrost, as has been observed further south near the Northwest Territories-British Columbia border (Carpino et al., 2018). In the Taiga Shield landscape, lake storage state can rapidly change the contributing area for runoff downstream and the landscape has a distinct threshold-response runoff regime (Ali et al., 2013). Wetlands are important "switches" in controlling the state of hydrological connectivity in the watersheds (Spence and Phillips, 2015). Permafrost thaw (and ultimately disappearance) may significantly affect this functioning, but it is unclear at what fraction of thaw progression major hydrological changes will occur.

\subsection{Groundwater interactions and Prairie wetland processes}

Over much of the Prairies and the Boreal Plain, groundwater discharge from shallow sand and gravel aquifers sustains year-round base flow in some small streams and can be an important component of the water balance of wetlands and of some lakes. Groundwater is thus important with respect to local water resources and in maintaining surface hydrological connectivity and ecosystem function. Groundwater provides rural water supplies and in some cases municipal supplies
(Peach and Wheater, 2014), and whilst it is not used as a major source for irrigation water outside of the southern-central parts of Manitoba, an issue facing some parts of the Prairies is the increasing reliance on groundwater as water demand rises and surface water becomes over-allocated (Council of Canadian Academies, 2009). Regional-scale groundwater depletion is not common in Canada, unlike other parts of North America (Rodell et al., 2018), but there have been numerous examples of isolated, human-induced local-scale depletion in Alberta (e.g., Munroe, 2015). The water-table records in shallow $(<20 \mathrm{~m})$ observation wells in the Prairie region show regular seasonal variations, with rises in spring and declines through the rest of the year. There were no large long-term changes during 1960-2000, a noticeable drop during the 2000-2004 drought, followed by a rise in the following decade (Hanesiak et al., 2011). There are very few long-term observation wells in the Boreal Plain, but the detailed records of water-table variations at the BERMS (Site 7, Fig. 1), together with hydrometeorological records, demonstrate the responses of the water table to changes in net water input to the subsurface throughout dry and wet periods and in various typical settings including peatlands and dry uplands (Anochikwa et al., 2012; Barr et al., 2012).

In the Prairies and Boreal Plain, lateral groundwater flow is slow due to the relatively flat terrain and the low permeability of the clay-rich glacial sediments underlying most of the landscape. As a result, subsurface water movement is mostly vertical - downward with infiltration, upward by root uptake - and the soil water and groundwater form a hydrological continuum. Rises of the water table are primarily driven by snowmelt infiltration and by focused recharge beneath ephemeral ponds in small wetlands and depressions that dry out within days or weeks after filling with snowmelt runoff (Bam et al., 2020). Recharge processes are sensitive to changes in snow accumulation, redistribution, and ablation processes (Sect. 3.2) and to land-use conversion (e.g., native grassland to cultivated fields, change in tillage practice), which influences soil hydraulic properties and snowmelt infiltration and runoff (van der Kamp et al., 2003). Most summer $P$ infiltrates only to the root zone and is taken up by vegetation, driving a seasonal decline of the water table (Hayashi et al., 2016). However, summer infiltration can lead to rises of the water table where it is near the ground surface, as in wetlands. As a result, the dynamics of the shallow groundwater table are strongly controlled by the balance between infiltration and ET in response to weather, vegetation, and seasons. It is also sensitive to inter-annual and inter-decadal fluctuations in $P$ (Hayashi and Farrow, 2014). The water table in the Prairie and Boreal regions can fluctuate quickly but is generally limited in range. When the water table rises near the ground surface, ET is increased and lateral groundwater flow to surface waters becomes important within the highly fractured near-surface materials (Hayashi et al., 2016; Brannen et al., 2015). This causes the water table to decline and 
provides the negative feedbacks to limit the range of watertable fluctuations to a few meters.

Groundwater processes are closely linked to the water regime (i.e., hydroperiod) of wetlands. Prairie wetlands occur in the form of shallow marshes ("sloughs" or "potholes") with little accumulation of organic matter, whereas Boreal wetlands primarily occur as peatlands. The spatial transition from Prairie marshes to Boreal peatlands is coincident with the transitional ecotone between the Prairie and Boreal Plain regions, described in Sect. 2 (see Ireson et al., 2015). The hydroperiod of prairie wetlands is essentially controlled by a balance between water inputs from snowmelt runoff and $P$, versus ET losses and sporadic overflow in wet periods (Hayashi et al., 2016). Groundwater outflow from these wetlands due to ET in the riparian zone also has a strong influence on the hydroperiod. Long-term (50+ years) data collected at the St. Denis WECC observatory (Fig. 1, site 8) have demonstrated the dominance of precipitation amounts in controlling the multi-decadal-scale variability in hydroperiod (Hanesiak et al., 2011; Hayashi et al., 2016).

The hydrology of Boreal peatlands has not been studied as extensively as that of Prairie wetlands, but studies of a fen in the BERMS (Barr et al., 2012) have shown that it has a large water storage capacity and supplies base flow to streams and to support the shallow water table in surrounding uplands during dry periods. In contrast, the fen sheds water quickly to streams during wet periods when the water table rises above the peat surface. Long-term studies in northern Alberta have shown that the type of glacial sediments has a large influence on the groundwater exchange and runoff generation from the peatlands (e.g., Devito et al., 2017).

Groundwater replenishment to deeper aquifers is restricted by the low permeability of overlying layers of clay, clayrich glacial till, and shale, and by the position of the aquifers within larger regional groundwater flow systems (Cummings et al., 2012). In the Prairies, replenishment rates to confined aquifers generally range from a few $\mathrm{mm}$ to a few tens of millimeters per year (van der Kamp and Hayashi, 1998). Recharge to the water table represents a residual in the water balance and is highly sensitive to changes in the balance between $P$ and ET; however, replenishment to deep aquifers is not sensitive to variations of the water table and therefore responds slowly to climate change.

In the Western Cordillera the interaction of groundwater with surface waters is in many ways different from the groundwater dynamics in the Boreal Plain and the Prairies. Groundwater plays an essential role in sustaining base flow in the mountain headwaters of large river systems (Paznekas and Hayashi, 2016), and may be of growing importance under climate change. Above the tree line in the Rocky Mountains, primary aquifers are sedimentary landforms such as talus, moraine, and rock glacier (Hood and Hayashi, 2015; Harrington et al., 2018; Hayashi, 2020; Christensen et al., 2020), except in areas with substantial karst systems. Groundwater storage in these landforms is relatively small compared to the SWE contained in the seasonal snow cover (Hood and Hayashi, 2015), and groundwater discharge exhibits a fast recession after snowmelt or rainfall events. However, this is generally followed by a slower recession and the remaining storage allows these aquifers to sustain stable base flow during the rest of the year when there is little recharge (Hayashi, 2020). The high topographic relief, together with significant heterogeneity in bedrock and surficial deposits, influences patterns of vertical and lateral groundwater flow and recharge and discharge processes. At lower elevations, aquifers include glacial and alluvial deposits of highly permeable sands and gravels that drape mountainsides and underlie valley bottoms, usually $10 \mathrm{~s}$ to $100 \mathrm{~m}$ thick, but in some instances up to several hundred meters in thickness (Toop and de la Cruz, 2002). These store larger quantities of water and provide a reliable supply for municipal and industrial uses. In floodplain areas, the water table is usually near the ground surface and fluctuates with river levels. Although mountain aquifers are able to buffer base flow against climate warming and associated changes in surface water availability (e.g., Paznekas and Hayashi, 2016), anecdotal evidence has indicated that they cannot sustain high flows in drought years, such as in 2015, when the spring-summer discharge of the Bow River fell to about half its median rate at Banff and to less than $10 \%$ at its mouth.

\section{Process-based modelling of change in CCRN}

Due to the complexity in process responses to climate and anthropogenic change in the CCRN domain and other cold regions, there is significant uncertainty associated with model projections of future hydrological change. While all models have limitations, detailed process-based models can yield important insights into interactions and feedbacks, and largescale models can be used with careful selection of possible scenarios to quantify likely effects of future change. Here we describe CCRN's efforts to improve model process representation, diagnose past change, and predict future change.

\subsection{Fine-scale diagnostic and predictive modelling}

Based on field studies and understanding from the WECC observatories, efforts were directed primarily at improving functionality and expanding the capability of handling complex cold-region processes within the Cold Regions Hydrological Modelling (CRHM) platform (Pomeroy et al., 2007; https://research-groups.usask.ca/hydrology/ modelling/crhm.php, last access: 6 April 2021). CRHM is a flexible modelling system that can be used to generate a process hydrology model, specific to the needs of the user and to the availability of driving meteorological data and of basin biophysical information to select parameters. A functioning model is built by selecting various process modules from a library; the modules incorporate algorithms or sub- 
models that are based on several decades of hydrological research. Process algorithms cover a wide range of phenomena specific to cold-region hydrology, which are then linked together to represent specific elements of the hydrological system and cycling over distinct landscape units termed "hydrological response units" (HRUs). Process studies and model developments focused on blowing snow transport and sublimation over complex terrain (Aksamit and Pomeroy, 2018, 2020); snowmelt in disturbed forests and on slopes; water flow through snowpacks (Leroux and Pomeroy, 2017, 2019); glacier snow, firn, and ice melt (Samimi and Marshall, 2017; Marshall and Miller, 2020; Anderson, 2017; Pradhananga, 2020); snow avalanching; soil moisture and hydraulic conductivity (Zwieback et al., 2019a); and freezing and thawing of soils (Krogh et al., 2017; Williamson et al., 2018; Rowlandson et al., 2018; Lara et al., 2020).

Improving process representation ultimately translates into increased realism and predictive capability. Marmot Creek (Fig. 1; site 2) provides a prime example of how the WECC observatories are valuable testbeds for model development. Pomeroy et al. (2012) and then Fang et al. (2013) developed a model for this basin using the CRHM platform, with parameterizations based on decades of intensive field science here and elsewhere, and showed very good model performance for snow accumulation and melt, soil moisture, groundwater, and stream discharge at the basin scale and for smaller sub-basins. They conducted "falsification" tests by neglecting parameterizations for forest canopy snow mass and energy, blowing snow, intercepted rain evaporation, and sublimation, which showed that without these, the model prediction of basin and sub-basin streamflow was substantially degraded. This approach, verified by successful internal simulation of sub-basin hydrological variability and model falsification, lends more confidence in the face of non-stationarity and for ungauged basins, where parameter equifinality and conceptual uncertainty are otherwise major challenges.

CRHM was applied at a number of the WECC observatories as well as other sites in western North America and run for historical periods using local meteorological observations, ERA-Interim (Dee et al., 2011), and/or bias-corrected WATCH (Weedon et al., 2011, 2014) forcing data. It was verified using field observations and then used to diagnose hydrological function of these basins, and predict and diagnose historical change, such as the impact of changing climate, wetland drainage, glacier shrinkage and ice exposure, permafrost thaw, and shrub growth/expansion on hydrological processes, cycling, and streamflow hydrographs. It has also been run for late 21 st century climates, downscaled using statistical and dynamical methods. Future sensitivity and change was examined by perturbing climate forcing using high-resolution WRF modelled pseudo global warming under RCP8.5 (see Krogh and Pomeroy, 2019) or using results from the North American Regional Climate Change Assessment Program (NARCCAP) consisting of 11 regional climate models driven by outputs from multiple global climate models (GCMs) for the SRES A2 emission scenario (see Rasouli et al., 2019). Hydrological responses to changing vegetation, soils, and land cover were examined using current and expected future states of the basins.

\subsection{Large-scale river basin modelling}

CCRN worked with partners in Environment and Climate Change Canada (ECCC) to advance the Modélisation Environmentale Communautaire (MEC) - Surface and Hydrology (MESH) model. MESH is a stand-alone land-surfacehydrology scheme designed for both forecasting and open loop simulations (Pietroniro et al., 2007). It uses a "grouped response unit" (GRU) approach to represent spatial heterogeneity for parameter identification, with CLASS as the surface water and energy budget simulation model for open loop simulations. As a hydrological modelling system, MESH captures many of the important land-surface processes necessary for cold-region simulation, provides a flexible modelling framework that facilitates inter-comparison of alternative algorithms and models (e.g., land-surface schemes and routing schemes), and can be applied over large river basins.

Over the course of CCRN, major advancements in the MESH system were made in terms of basic operability, scalability, and parallelization, as well as in its ability to handle sloping and complex terrain, permafrost (Sapriza-Azuri et al., 2018; Elshamy et al., 2020), lakes and wetlands, snow processes and glacier representation, vegetation processes including snow-canopy interactions (Bartlett and Verseghy, 2015; Asaadi et al., 2018), frozen soils and Prairie hydrology including variable hydrological connectivity (Mekonnen et al., 2014), and water management impacts including reservoirs, diversions, and irrigation (Yassin et al., 2019). The work has progressed to a point at which functioning MESH models for the Mackenzie and Saskatchewan River systems have been developed, calibrated, and tested (Yassin et al., 2017, 2019; Bahrami et al., 2020).

MESH has been run for historical (1980-2010) and future $(2025-2055 ; 2070-2100)$ climates at a $10 \mathrm{~km}$ resolution, incorporating these advancements in process and water management representation, to examine changes in regional hydrology and river flows. Forcing data included WATCH and ERA-Interim products (Weedon et al., 2011, 2014) with bias correction using regional datasets such as the combined Global Environmental Multiscale (GEM) atmospheric model forecasts and the Canadian Precipitation Analysis (CaPA) (Fortin et al., 2018). Regional climate projections for future MESH simulations to the end of the 21st century were derived from 15 ensemble members from the CORDEX-NA CanRCM4 under the RCP8.5 emissions scenario. Climate fields were spatially downscaled and bias-corrected against the WATCH ERA-Interim reanalysis - GEM - CaPA product (Asong et al., 2020). Evaluation of the historical simulations has shown that the model performed quite well, with Nash-Sutcliffe Efficiencies for river discharge greater 
than 0.5 at $60 \%$ of observation stations in the Saskatchewan River Basin and greater than 0.6 for most stations along the main stem of the Mackenzie River and its major tributaries (Peace, Athabasca, Slave, Liard, and Great Bear). Major efforts have been needed to develop robust algorithms for simulation of permafrost, glacier, and vegetation change, and the development of scenarios of future land cover change. These have now been prepared and the next phase of the work is to run the models for full (i.e., climate and land cover) future assessment. Scenario results are currently pending, but some preliminary insights are discussed below.

\section{Synthesis of future change and hydrological responses}

New understanding and insight into process sensitivity, interactions, and responses (Sect. 3), together with expert elicitation and process-based modelling (Sect. 4), have allowed more scientifically informed projections of future ecological, cryospheric, and hydrological change than have hitherto been available. Here, these are brought together, informed by the new research results from CCRN, to develop a summary picture largely applicable to the late 21 st century (Fig. 9).

Future climate is expected to lead to profound changes in land cover and vegetation. In the mountain regions, one of the most striking changes will be the loss of glaciers. The lower parts of many glaciers will have disappeared within decades or less, while upland icefields may persist but in a much diminished state. By the late 21 st century only vestigial remnants of the former ice cover and small glaciers in favorable locations for ice preservation will likely remain. Over a much larger part of the CCRN domain, and of greater magnitude of change, will be the response of vegetation and forest ecosystems to climate change and climate-induced disturbances. At northern and alpine tundra and tree line ecotones, shrub growth and expansion in tundra will continue and is expected to accelerate over the latter half of the 21 st century. A northern and upward shift in tree line is likely but will occur more slowly and be far less pronounced than for shrub expansion. Across the contiguous Boreal Forest, the major transition will be the loss of ENF and major expansion of DBF and jack pine forest stands, wetlands (in the north), and, to a lesser extent, grasslands (e.g., in valley bottom areas of the Cordillera). Permafrost thaw and collapse of permafrost-underlain spruce forest and peat plateaus will accelerate over vast parts of the Taiga Plain. At the southern Boreal-Prairie ecotone and over the Boreal Plain, northward expansion of deciduous shrubs and concomitant loss of deciduous and mixed-wood forest will continue, leading to the expansion of grassland in these areas into the late 21 st century.

In addition, human activities, land-water management practices, and changes in agricultural cropping patterns will further alter landscapes. These are likely to be most pro- nounced in the Prairie and southern Boreal parts of the CCRN region. Climate warming will further drive changes in crop mix and spatial patterns, with new crops such as corn becoming more widespread, and northward expansion of other crops such as canola, wheat, and soy (Hannah et al., 2020). Climatic and land suitability limitations will restrict how, where, and the timescales over which this occurs. For example, parts of southern Alberta will experience more extreme heat and heat stress days above $30^{\circ} \mathrm{C}$, resulting in declining crop production even with sufficient moisture. In Saskatchewan, work by Coles et al. (2017) has suggested for planted hillslopes, measured decreased snowfall, snowmelt runoff, and spring soil water content is affecting agricultural productivity through increased dependence on growing season precipitation, likely accentuating the future impact of droughts. Areas vulnerable to drought, such as the Palliser Triangle of southern Alberta and Saskatchewan, and where soils have low moisture storage capacity, will most likely undergo conversion to pasture and grassland as arable agriculture becomes non-viable. Other areas may require irrigation to remain viable, and with agricultural expansion and more water-intensive forms of crop production, there will be increased irrigation demand (Council of Canadian Academies, 2013) and possibly a need for more reservoirs. The northward expansion of agriculture will occur in nodes as infrastructure and roads develop, and be limited by the suitability of soils. Another major change in parts of the agricultural zone is the artificial drainage of wetlands, which has various impacts on runoff, erosion, sediment transport, groundwater recharge, and water quality (Pomeroy et al., 2014; Shook et al., 2015). While recent polices have been implemented to limit drainage (or minimize the impacts), the trend will likely continue, especially in wetter regions to the east and in the face of hydro-climatic change resulting in more spring and summer flooding (Stewart et al., 2019), although the potential exists for wetland restoration to mitigate these effects.

The combined changes in climate, vegetation, soils, and land cover will have major effects on hydrology. CRHM outputs show that the loss of cold in the CCRN region is expected to cause dramatic shifts in the timing, variability, and volume of streamflow, and even more profoundly, on the processes generating streamflow. There is sometimes compensation by changing vegetation but also instances where vegetation and soil change enhance the magnitude of climate change impacts on hydrology. Summary results from the CRHM applications at several observatory basins in different ecological regions are provided in Table 1. Results for a number of other basins are pending. These studies show a tendency for increasing total discharge and earlier spring freshet in these headwater basins, as a result of warmer and wetter late 21 st century conditions but mixed trends in SWE and peak discharge rates. Within Marmot Creek, anticipated warming will cause basin-wide peak SWE to decline by about $30 \%$ to $40 \%$ but by as much $90 \%$ in some parts of the basin, with valley bottoms becoming almost en- 

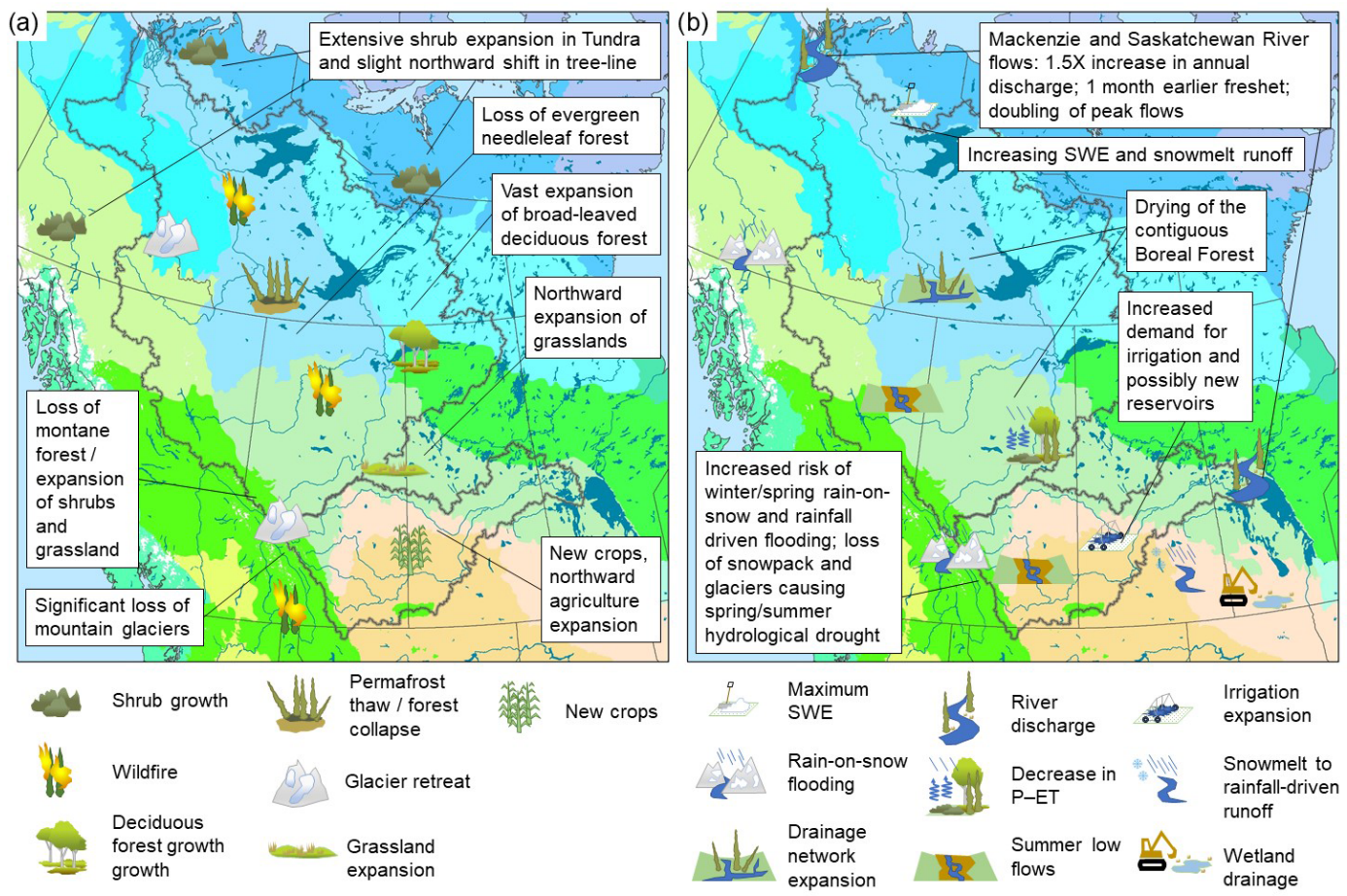

Figure 9. Conceptual depiction and synthesis of surface changes over the CCRN region, by the late 21st century, for (a) land cover and vegetation and (b) hydrological regime and water management. The base map depicts the Level II Ecological Regions of North America as shown in Fig. 1.

tirely snow-free, and an accompanying shift in snow cover depletion of up to 6 weeks. Yet the increase in $P$ leads to a roughly $20 \%$ increase in total discharge. Farther north at Wolf Creek, where conditions are colder, climate change impacts on snow regime are projected to be less severe and vegetation change (expansion of forest and shrub tundra) is projected to have a compensatory influence. Here, a statistically insignificant increase in SWE due to vegetation increase in the alpine zone was found to offset the statistically significant decrease in SWE due to climate change. At high elevations in Wolf and Marmot Creeks, CHRM results indicate that vegetation/soil changes moderate the impact of climate change on peak SWE, the timing of peak SWE, evapotranspiration, and annual runoff volume. However, at medium elevations, these changes intensify the impact of climate change, further decreasing peak SWE and sublimation. At Havikpak Creek near the Taiga-Tundra transition, where significant expansion of shrubs is expected, maximum SWE will increase as a result of increasing $P$ and reduced blowing snow redistribution and sublimation. This is expected to double the volume of discharge, and significantly increase spring freshet volume, snowmelt rates and peak discharge rates.

CRHM was also applied to the Bow $\left(\sim 7824 \mathrm{~km}^{2}\right)$ and Elbow $\left(\sim 1192 \mathrm{~km}^{2}\right)$ River Basins above the city of Calgary, $\mathrm{AB}$, and run to diagnose the hydrological effects of forest disturbance in these basins in the context of the June 2013 flood event. The land cover scenarios are at a finer resolution than those shown in Figs. 6 and 7 but capture the same essential features and in agreement for wildfire and the loss ENF projected for the late 21 st century. Other scenarios included harvesting of lodgepole pine and disturbance by mountain pine beetle. The results show that for both rivers, high wildfire severity and secondarily mountain pine beetle infestation with salvage logging resulted in an increase in streamflow volume. High wildfire severity followed by mountain pine beetle with salvage logging and maximum harvest area scenarios increased the volume and daily discharge of the June 2013 flood. Other forest disturbance scenarios had minimal impacts on streamflow. Thus, wildfire and loss of montane forests in such intermediate sized basins of the mountain headwaters are likely to have a notable impact on flow regime in future.

For the larger Saskatchewan and Mackenzie River systems, the results of MESH simulations over the Saskatchewan and Mackenzie River Basins indicate that future climate conditions will lead to considerable shifts in discharge timing, magnitude, and variability. The results are provisional and do not yet fully account for changing landscapes and vegetation, but initial MESH climate production runs indicate there is likely to be a shift in timing of spring hydrograph rise and peak flows of nearly 2 weeks earlier by mid century, and as much as 1 month by late century. Fine-scale MESH runs on the mountain-sourced Bow and Elbow River Basins, driven by WRF, and with adjust- 


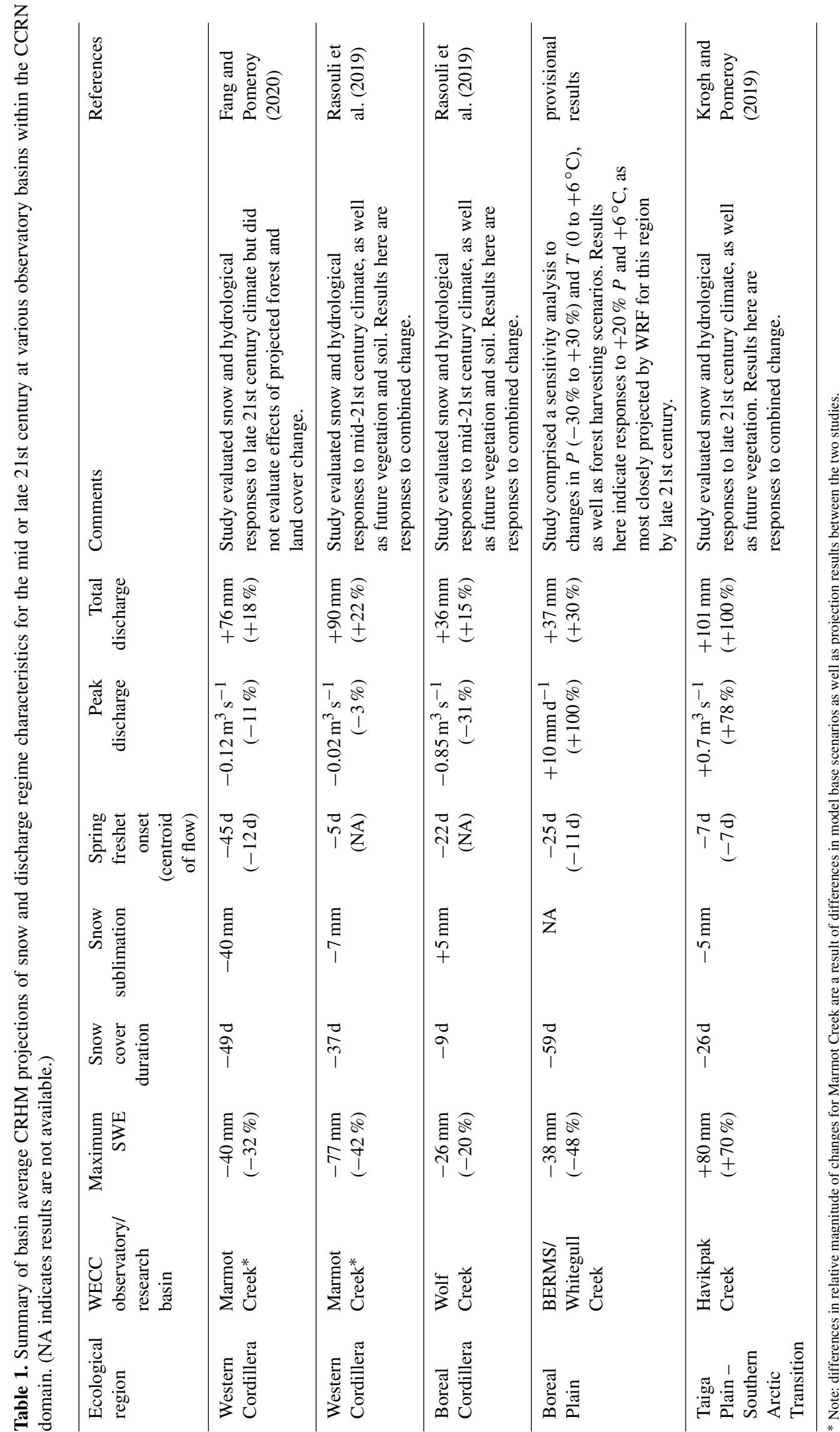


ments for slope, aspect and elevation, were able to capture the main river hydrographs well and demonstrate how this forward shift in freshet is a result of a transition to much more rainfall-runoff generation as rainfall increases and snowpacks decline in the late 21 st century (Tessema et al., 2020). The MESH models of the Saskatchewan and Mackenzie River Basins further show that increasing $P$ across the CCRN region of interest is not offset by increasing ET, and overall flow volume increases by as much as $40 \%$ by the end of the century. Low flows in winter become slightly higher in magnitude but with more inter-annual variability, and there is a likely considerable increase in spring freshet volume and peak flows. By late century these spring flows, on average, will increase by a factor of 1.5 to 2 ; the greater variability and higher peak flows at most locations along the river network will greatly increase the risk of spring flooding. This is likely to stress human water management systems and reservoir operations, as river discharge regimes may be altered far beyond the historical flow ranges, seasonality, and variability under which these systems were designed and operated.

\section{Further research priorities and concluding remarks}

This article reports results of the multi-disciplinary CCRN, which has examined recent and future ecological, cryospheric, and hydrological change in relation to projected 21st century climatic change over the interior of western and northern Canada. Key insights into the mechanisms and interactions of Earth surface process responses are presented, gained from a network of highly instrumented and intensively studied experimental observatories. This provided the ability to observe and diagnose change across the region, while the sites acted as a testbed for developing and improving predictive models. CCRN activities also involved improving cold-region process representation within the CRHM fine-scale and MESH large-scale modelling systems. Application of the fine-scale modelling system has been used to diagnose recent change in selected basins and the nature of future change. Broader application of the finescale and large-scale models under future climate and land cover scenarios, representing mid and late 21 st century conditions, is currently underway with support of the Global Water Futures program (https://gwf.usask.ca/, last access: 6 April 2021).

In general, insights from expert elicitation and preliminary modelling indicate that the region will continue to undergo widespread environmental change as a result of warmer temperatures and changing $P$ regimes. This will predominantly involve continued loss of snow and ice, thawing of permafrost, major ecosystem change and an increase in the occurrence and magnitude of wildfire, and a shift from nival and glacial to more rainfall-driven pluvial runoff regimes. Intensifying floods and increased risk of drought can also be expected. However, some of the process responses are non-trivial and highly complex. To understand the trajectories of different northern ecological, cryospheric, and hydrological systems under climate change, the details of these processes and their interactions are very important. This can have unanticipated and sometime surprising outcomes that simple models or extrapolations will fail to capture.

There are many gaps to be addressed by further research and priorities for model development. Most currentgeneration land-surface schemes and hydrological models do not handle a dynamic landscape where vegetation, glaciers, permafrost distribution, etc. are transient, and there is large uncertainty in their application under a non-stationary hydroclimatic regime. Human interventions also have a large influence through activities such as forest disturbance, agricultural and forest land management, water abstractions for consumptive use, diversions, and reservoir operations, which further alter ecological and hydrological systems. Improved physical process representation is required to handle these complexities and interactions, while models need to be applied at spatial and temporal scales that can properly resolve the dominant drivers of hydrological change. New and more sophisticated sensors and remote sensing technologies are providing improved measurement capabilities and possibilities for more detailed and spatially extensive observations of hydrological states and fluxes. This can provide the data necessary to quantify landscape and hydrological change and to test and validate improved models, but over much of Canada and other remote, cold regions globally such observations are still very sparse. There is a need to expand integrated observation and prediction systems, as exemplified by the activities at many of the CCRN WECC observatories.

Another critical issue relates, in part, to long-term data acquisition and organization. Climate monitoring and observation are key to understanding its variability and trends, and for providing input to land-surface and hydrological models, yet this is a major challenge in cold regions. Forcing data remains one of the largest source of uncertainty for historical simulations. In Canada, and especially in its alpine and northern regions, there is a sparse observational network, with problems related to station automation and major challenges associated with the measurement of solid $P$ (Rasmussen et al., 2012), thus requiring high priority to expanding the network and to better measuring snowfall (Bush and Lemmen, 2019).

Modelling across spatial scales is advantageous for more fully examining hydrological change. Fine-scale and detailed process-based models yield important insights into interactions and feedbacks but are often applied over small domains such as intensively studied headwater research basins, and for experimental research purposes. Large-scale models can be used with careful selection of possible scenarios to quantify likely effects of future change over broad regions and large river basins but typically have coarser resolution and less detailed treatment of physical processes. These 
simpler large-scale models tend to be used in operational forecasting systems. The CRHM and MESH modelling platforms provide a unique capability to represent the complex, energy-dominated processes that control cold-region hydrology. While further work is underway on scenario analysis, there are also continuing needs for the development of flexible and robust models with the capability to capture coldregion processes and bridge scales from local to regional to large basin scale. This will form the next generation of advanced modelling and prediction tools, harnessing the increasingly available computational power.
Finally, these developments need to be informed by new transdisciplinary science and collaboration (Wheater and Gober, 2015). A major challenge among water researchers is the fragmented approach to addressing these issues, which are complex and transcend disciplines among natural sciences, engineering, and computer science. Social science also has a key role, particularly with regards to engaging user and stakeholder communities in the co-development of research and in using more effective mechanisms to translate new scientific knowledge into societal action. 
Appendix A: Developing future land cover maps for hydrological modelling

This Appendix describes our approach to generating future land cover scenarios for hydrological modelling, based on observational and modelling studies, and expert elicitation. The scenarios were developed for use in the MESH hydrological model to address this question: what is the potential for vegetation changes to affect 21 st century streamflow in the Saskatchewan and Mackenzie River Basins? The approach generated future scenarios by applying a realistic change signal to the current MESH land cover map.

The change signal was derived from a Random Forest classification tree (RFCT) (Rehfeldt et al., 2012), using an updated analysis from 2017. The RFCT products included a base land cover map that was used to represent 2005, and projected maps for 2025, 2055 and 2085 based on climate scenarios from RCP8.5. Before computing the change signal, the RFCT vegetation classes were aggregated into nine land cover types that could be easily related to the MESH plant functional types (PFTs); the RFCT grid was mapped onto the MESH grid $\left(0.125 \times 0.125^{\circ}\right)$; the land cover fractions were computed for each MESH grid square; and the 2025 and 2055 maps were averaged to represent 2040. The vegetation change signal was then computed for each land cover type as the difference in the fractional cover between the projected and base maps (2040 minus 2005 and 2085 minus 2005).

The RFCT analysis did not include four of the MESH PFTs (Wetlands, Water, Ice, or Urban). Consequently, it was necessary to limit the changes in fractional coverage to seven CLASS PFTs (Deciduous Broadleaf Forest (DBF), Evergreen Needleleaf Forest (ENF), Mixedwood Forest (MWF, SK Basin only), Cropland, Grassland, Shrubland, Tundra, and Barren). The Shrubland and Tundra PFTs were identical to Grassland except for height and leaf area index. In addition, the RFCT represented prairie Grassland and Cropland as one vegetation class, so that it was not possible to represent changes due to competition between the two.

The resulting unmodified RFCT change signals for 2005 to 2040 and 2005 to 2085 represent the land cover changes that would be expected if climate was the only factor limiting vegetation migration. In reality, vegetation migration is also limited by the rates of colonization, and in some cases, by additional constraints such as the need for wildfire as a trigger. We used expert knowledge to eliminate unrealistic changes from the RFCT change signal, retaining only changes that were deemed to be plausible over the 21st century. The plausible changes are listed in Table A1, with associated conditions and constraints. For land cover changes that normally occur only after wildfire (ENF to Grassland and ENF to DBF, Table A1), the analysis added two further constraints. The area burned was estimated assuming a prescribed fire-return interval which varied with latitude (Table A2). The resulting, constrained change signal represented the maximum plausible change for each land cover type.

Finally, 2040 and 2085 projections of the MESH land cover map were created by applying the change signal to the current MESH land cover base maps. The main changes included

- to the south and west, a northward and upward (elevational) shift in the forest-grassland ecotone in response to

- land clearing for agriculture (Cropland expansion into DBF, using the presence of DBF to indicate soils that were suitable for agriculture);

- partial replacement of ENF by Grassland and Shrubland following wildfire;

- within the contiguous forest, wildfire-induced partial replacement of ENF by DBF;

- at the northern and alpine tree line, displacement of Shrubland by ENF in areas where ENF is already present; and

- above the northern and alpine tree lines, Shrubland expansion into Tundra.

The strategy of applying a RFCT change signal to the current land cover map, with modifications based on constraints from expert knowledge, has several advantages over using the RFCT projections directly. It anchors the projections to the current land cover map, potentially increasing their realism. It eliminates changes that are implausible over the modelling time frame (21st century). It integrates wildfire as a trigger for changes that most often occur after fire. It also preserves the characteristic patchiness of the Boreal Forest mosaic. Note that the resulting land cover projections are intended for use in hydrological modelling only; at best, they represent an informed guess of the likely changes. Caution is advised against using them in other applications. 
Table A1. Projecting future changes in the MESH land cover map over the 21st century: changes in the MESH plant functional types (PFTs); changes in the RFCT land covers that were used to identify areas of change; and the associated conditions and constraints. The changes were implemented separately for each MESH grid square, when all three necessary conditions (1-3) and the associated constraints were met.

\begin{tabular}{|c|c|c|c|c|c|c|c|}
\hline \multirow[t]{2}{*}{ Description } & \multicolumn{3}{|c|}{ Necessary conditions } & \multirow{2}{*}{$\begin{array}{l}\text { Projected } \\
\text { CLASS } \\
\text { PFT }\end{array}$} & \multirow[t]{2}{*}{ Constraints } & \multirow{2}{*}{$\begin{array}{r}\% \text { area } \\
\text { conversion } \\
2005-2085 \\
\text { SK Basin }\end{array}$} & \multirow{2}{*}{$\begin{array}{r}\% \text { area } \\
\text { conversion } \\
2005-2085 \\
\text { Mackenzie } \\
\text { Basin }\end{array}$} \\
\hline & $\begin{array}{l}\text { 1. RFCT } \\
\text { land } \\
\text { cover } \\
\text { (base } \\
\text { map) }\end{array}$ & $\begin{array}{l}\text { 2. Projected } \\
\text { RFCT } \\
\text { land cover } \\
(2040 \text { or } 2085)\end{array}$ & $\begin{array}{l}\text { 3. CLASS } \\
\text { PFT } \\
(2005 \\
\text { base } \\
\text { map) }\end{array}$ & & & & \\
\hline $\begin{array}{l}\text { Agricultural } \\
\text { expansion into } \\
\text { Aspen Parkland } \\
\text { and southern } \\
\text { Boreal MWF/DBF }\end{array}$ & $\begin{array}{l}\text { Aspen } \\
\text { Parkland } \\
\text { or } \\
\text { Boreal } \\
\text { MWF }\end{array}$ & $\begin{array}{l}\text { Great Plains } \\
\text { Grassland }\end{array}$ & $\mathrm{DBF}$ & Cropland & $\begin{array}{l}80 \% \text { conversion; } \\
20 \% \text { retained as } \\
\text { DBF }\end{array}$ & $0.2 \%$ & $1.5 \%$ \\
\hline $\begin{array}{l}\text { Encroachment of } \\
\text { Aspen Parkland } \\
\text { into southern } \\
\text { Boreal MWF/DBF }\end{array}$ & $\begin{array}{l}\text { Boreal } \\
\text { MWF }\end{array}$ & Aspen Parkland & $\begin{array}{l}\text { DBF } \\
\text { or } \\
\text { MWF }\end{array}$ & $\begin{array}{l}50 \% \\
\text { Cropland } \\
50 \% \mathrm{DBF}\end{array}$ & $\begin{array}{l}50 \% \text { conversion; } \\
50 \% \text { retained as } \\
\text { DBF }\end{array}$ & $1.6 \%$ & $0.4 \%$ \\
\hline $\begin{array}{l}\text { Encroachment of } \\
\text { Aspen Parkland } \\
\text { into southern } \\
\text { Boreal ENF }\end{array}$ & $\begin{array}{l}\text { Boreal } \\
\text { MWF }\end{array}$ & Aspen Parkland & ENF & Grassland & $\begin{array}{l}50 \% \text { conversion; } \\
50 \% \text { retained as } \\
\text { ENF }\end{array}$ & $0.2 \%$ & $0.2 \%$ \\
\hline $\begin{array}{l}\text { Post-fire } \\
\text { replacement of } \\
\text { ENF by Grassland } \\
\text { near forest- } \\
\text { Grassland ecotone }\end{array}$ & $\begin{array}{l}\text { Aspen } \\
\text { Parkland } \\
\text { or } \\
\text { Boreal } \\
\text { MWF }\end{array}$ & $\begin{array}{l}\text { Great Plains } \\
\text { Grassland }\end{array}$ & ENF & Grassland & $\begin{array}{l}\text { Limited to } \\
\text { burned area; } \\
\text { conversion rate } \\
\text { from } 75 \% \text { in the } \\
\text { varying }\end{array}$ & $0.2 \%$ & $0.1 \%$ \\
\hline $\begin{array}{l}\text { Post-fire } \\
\text { replacement of } \\
\text { ENF by DBF in } \\
\text { Boreal ENF }\end{array}$ & $\begin{array}{l}\text { Bo } \\
(\mathrm{n} \\
\mathrm{Bo} \\
(\mathrm{n}\end{array}$ & $\begin{array}{l}\text { chal MWF } \\
\text { change) } \\
\text { eal ENF } \\
\text { change) }\end{array}$ & ENF & DBF & $\begin{array}{l}\text { south }\left(53^{\circ} \mathrm{N}\right) \\
\text { to } 25 \% \text { in the } \\
\text { north }\left(63^{\circ} \mathrm{N}\right)\end{array}$ & $1.1 \%$ & $2.8 \%$ \\
\hline $\begin{array}{l}\text { Encroachment of } \\
\text { ENF into } \\
\text { Shrubland at tree } \\
\text { line }\end{array}$ & $\begin{array}{l}\text { Mixed } \\
\text { ENF and } \\
\text { Shrubland }\end{array}$ & ENF & $\begin{array}{l}\text { Grassland } \\
\text { or shrub }\end{array}$ & ENF & $\begin{array}{l}\text { Some ENF } \\
\text { already present }\end{array}$ & NA & $0.5 \%$ \\
\hline $\begin{array}{l}\text { Shrubland } \\
\text { expansion into } \\
\text { Tundra }\end{array}$ & $\begin{array}{l}\text { Tundra } \\
\text { or } \\
\text { barren }\end{array}$ & $\begin{array}{l}\text { Boreal MWF } \\
\text { or ENF } \\
\text { or mixed } \\
\text { ENF/Shrubland } \\
\text { or Shrubland }\end{array}$ & Tundra & Shrubland & None & NA & $5.0 \%$ \\
\hline $\begin{array}{l}\text { Tundra expansion } \\
\text { into barren }\end{array}$ & Barren & $\begin{array}{l}\text { ENF } \\
\text { or mixed } \\
\text { ENF/Shrubland } \\
\text { or Shrubland } \\
\text { or Tundra }\end{array}$ & Barren & Tundra & None & NA & $2.5 \%$ \\
\hline
\end{tabular}


Table A2. CCRN expert-guided north-south gradients in the post-fire conversion of ENF to DBF in the contiguous Boreal and Taiga Forest.

\begin{tabular}{lrccr}
\hline Location & $\begin{array}{r}\text { Fire } \\
\text { return } \\
\text { interval } \\
\text { (years) }\end{array}$ & $\begin{array}{c}\text { ENF fraction } \\
\text { burned in } \\
45 \text { years }\end{array}$ & $\begin{array}{c}\text { Conversion } \\
\text { rate }\end{array}$ & $\begin{array}{r}\text { Fraction } \\
\text { converted } \\
\text { from ENF } \\
\text { to DBF }\end{array}$ \\
\hline North $\left(63^{\circ} \mathrm{N}\right)$ & 120 & $31 \%$ & $25 \%$ & $8 \%$ \\
Mid $\left(58^{\circ} \mathrm{N}\right)$ & 100 & $36 \%$ & $50 \%$ & $18 \%$ \\
South $\left(53^{\circ} \mathrm{N}\right)$ & 80 & $43 \%$ & $75 \%$ & $32 \%$ \\
\hline
\end{tabular}


Data availability. Data are available through the cited sources throughout the text. WECC data from the CCRN study period are described and accessible within a special issue of the journal Earth System Science Data, titled Water, ecosystem, cryosphere, and climate data from the interior of Western Canada and other cold regions (https://essd.copernicus.org/articles/special_issue901.html, last access: 6 April 2021) (DeBeer et al., 2021). CCRN data are also accessible through the network website (http://www.ccrnetwork. ca/, last access: 6 April 2021) (CCRN, 2021) and the Global Water Futures program website (http://www.globalwaterfutures.ca, last access: 6 April 2021) (GWF, 2021).

Author contributions. The article was led by CMD and HW, with the help of JP. All the authors provided material and assisted with the writing and editing process, with valuable contributions in their individual fields of expertise. The future vegetation scenarios described in Appendix A and presented in Figs. 6 and 7 were led by AGB with the help of JLB, JFJ, MRT, and EC.

Competing interests. The authors declare that they have no conflict of interest.

Special issue statement. This article is part of the special issue "Understanding and predicting Earth system and hydrological change in cold regions". It is not associated with a conference.

Acknowledgements. We are grateful for financial support to CCRN from the Natural Sciences and Engineering Research Council of Canada (NSERC) through their Climate Change and Atmospheric Research (CCAR) program. We thank Garry Clarke, who provided future glacier change animations appearing in Fig. 5, and Mohamed Abdelhamed, who provided assistance with the vegetation scenarios in Figs. 6 and 7. We also wish to thank the anonymous reviewer and Francesco Avanzi, along with the handling editor, Carlo De Michele, for their positive feedback and helpful suggestions, which improved the manuscript.

Financial support. This research has been supported by the Natural Sciences and Engineering Research Council of Canada (grant no. 433923-2012).

Review statement. This paper was edited by Carlo De Michele and reviewed by Francesco Avanzi and one anonymous referee.

\section{References}

Aksamit, N. O. and Pomeroy, J. W.: Scale Interactions in Turbulence for Mountain Blowing Snow, J. Hydrometeorol., 19, 305320, https://doi.org/10.1175/JHM-D-17-0179.1, 2018.

Aksamit, N. O. and Pomeroy, J. W.: Warm-air entrainment and advection during alpine blowing snow events, The Cryosphere, 14 2795-2807, https://doi.org/10.5194/tc-14-2795-2020, 2020.

Ali, G., Oswald, C. J., Spence, C., Cammeraat, E. L., McGuire, K. J., Meixner, T., and Reaney, S. M.: Towards a unified threshold-based hydrological theory: necessary components and recurring challenges, Hydrol. Process., 27, 313-318, https://doi.org/10.1002/hyp.9560, 2013.

Anderson, E. R.: Modelling changes in multi-decadal streamflow contributions - Bologna Glacier, Selwyn Mountains, NWT, Canada, MSc Thesis, University of Saskatchewan, Centre for Hydrology, Saskatoon, p. 162, 2017.

Anochikwa, C. I., van der Kamp, G., and Barbour, S. L.: Interpreting pore-water pressure changes induced by water table fluctuations and mechanical loading due to soil moisture changes, Can. Geotech. J., 49, 357-366, https://doi.org/10.1139/t11-106, 2012.

Asaadi, A., Arora, V. K., Melton, J. R., and Bartlett, P.: An improved parameterization of leaf area index (LAI) seasonality in the Canadian Land Surface Scheme (CLASS) and Canadian Terrestrial Ecosystem Model (CTEM) modelling framework, Biogeosciences, 15, 6885-6907, https://doi.org/10.5194/bg-156885-2018, 2018.

Asong, Z. E., Elshamy, M. E., Princz, D., Wheater, H. S., Pomeroy, J. W., Pietroniro, A., and Cannon, A.: High-resolution meteorological forcing data for hydrological modelling and climate change impact analysis in the Mackenzie River Basin, Earth Syst. Sci. Data, 12, 629-645, https://doi.org/10.5194/essd-12629-2020, 2020.

Bahrami, A., Goïta, K., Magagi, R., Davison, B., Razavi, S., Elshamy, M., and Princz, D.: Data assimilation of satellite-based terrestrial water storage changes into a hydrology land-surface model, J. Hydrol., 125744, https://doi.org/10.1016/j.jhydrol.2020.125744, 2020.

Baltzer, J. L., Veness, T., Sniderhan, A. E., Chasmer, L. E., and Quinton, W. L.: Forests on thawing permafrost: fragmentation, edge effects, and net forest loss, Global Change Biol., 20, 824834, https://doi.org/10.1111/gcb.12349, 2014.

Bam, E. K. P., Ireson, A. M., van der Kamp, G., and Hendry, J. M.: Ephemeral ponds: Are they the dominant source of depressionfocused groundwater recharge?, Water Resour. Res., 56, e24508, https://doi.org/10.1029/2019WR026640, 2020.

Barr, A. G., van der Kamp, G., Black, T. A., McCaughey J. H., and Nesic, Z.: Energy balance closure at the BERMS flux towers in relation to the water balance of the White Gull Creek watershed 1999-2009, Agr. Forest Meteorol., 153, 3-13, https://doi.org/10.1016/j.agrformet.2011.05.017, 2012.

Bartlett, P. A., and Verseghy, D. L.: Modified treatment of intercepted snow improves the simulated forest albedo in the Canadian Land Surface Scheme, Hydrol. Process., 29, 3208-3226, https://doi.org/10.1002/hyp.10431, 2015.

Bentz, B. J., Régnière, J., Fettig, C. J., Hansen, E. M., Hayes, J. L., Hicke, J. A., Kelsey, R. G., Negrón, J. F., and Seybold, S. J.: Climate change and bark beetles of the western United States and Canada: direct and indirect effects, BioScience, 60, 602-613, https://doi.org/10.1525/bio.2010.60.8.6, 2010. 
Berg, E. E., Henry, J. D., Fastie, C. L., De Volder, A. D., and Matsuoka, S. M.: Spruce beetle outbreaks on the Kenai Peninsula, Alaska, and Kluane National Park and Reserve, Yukon Territory: Relationship to summer temperatures and regional differences in disturbance regimes, Forest Ecol. Manage., 227, 219232, https://doi.org/10.1016/j.foreco.2006.02.038, 2006.

Bergengren, J. C., Waliser, D. E., and Yung, Y. L.: Ecological sensitivity: a biospheric view of climate change, Climatic Change, 107, 433-457, https://doi.org/10.1007/s10584011-0065-1, 2011.

Black, T. A. and Jassal, R. S.: Evapotranspiration, in: Ecosystems: A Biogeoscience Approach, edited by: Johnson, E. and Martin, Y., Cambridge University Press, Oxford, UK, 2016.

Brannen, R., Spence, C., and Ireson, A.: Influence of shallow groundwater-surface water interactions on the hydrological connectivity and water budget of a wetland complex, Hydrol. Process., 29, 3862-3877, https://doi.org/10.1002/hyp.10563, 2015.

Brown, C. D. and Johnstone, J. F.: Once burned, twice shy: Repeat fires reduce seed availability and alter substrate constraints on Picea mariana regeneration, Forest Ecol. Manage., 266, 34-41, https://doi.org/10.1016/j.foreco.2011.11.006, 2012.

Brown, C. D., Dufour-Tremblay, G., Jameson, R. G., Mamet, S. D., Trant, A. J., Walker, X. J., Boudreau, S., Harper, K. A., Henry, G. H. R., Hermanutz, L., Hofgaard, A., Isaeva, L., Kershaw, G. P., and Johnstone, J. F.: Reproduction as a bottleneck to treeline advance across the circumarctic forest tundra ecotone, Ecography, 42, 137-147, https://doi.org/10.1111/ecog.03733, 2019.

Brown, R., Marsh, P., Déry, S., and Yang, D.: Snow cover - Observations, processes, changes, and impacts on northern hydrology, in: Arctic Hydrology, Permafrost and Ecosystems, edited by: Yang, D. and Kane, D., Springer, Cham, 61-99, https://doi.org/10.1007/978-3-030-50930-9_3, 2020.

Brown, R. D., Derksen, C., and Wang, L.: A multi-data set analysis of variability and change in Arctic spring snow cover extent, 1967-2008, J. Geophys. Res., 115, D16111, https://doi.org/10.1029/2010JD013975, 2010.

Burn, C. R. and Kokelj, S. V.: The environment and permafrost of the Mackenzie Delta area, Permafrost Periglac., 20, 83-105, https://doi.org/10.1002/ppp.655, 2009.

Burn, D. H. and Whitfield, P. H.: Changes in floods and flood regimes in Canada, Can. Water Resour. J., 41, 139-150, https://doi.org/10.1080/07011784.2015.1026844, 2016.

Burn, D. H. and Whitfield, P. H.: Changes in flood events inferred from centennial length streamflow data records, Adv. Water Resour., 121, 333-349, https://doi.org/10.1016/j.advwatres.2018.08.017, 2018.

Bush, E. and Lemmen, D. S. (Eds.): Canada's changing climate report, Government of Canada, Ottawa, Ontario, 444 pp., available at: https://changingclimate.ca/CCCR2019/ (last access: 6 April 2021), 2019.

Campbell, E. M., Antos, J. A., and van Akker, L.: Resilience of southern Yukon boreal forests to spruce beetle outbreaks, Forest Ecol. Manage., 433, 52-63, https://doi.org/10.1016/j.foreco.2018.10.037, 2019.

Carpino, O. A., Berg, A. A., Quinton, W. L., and Adams, J. R.: Climate change and permafrost thaw-induced boreal forest loss in northwestern Canada, Environ. Res. Lett., 13, 084018, https://doi.org/10.1088/1748-9326/aad74e, 2018.
CCRN - Changing Cold Regions Network: http://www.ccrnetwork. ca/, last access: 6 April 2021.

CEC - Commission for Environmental Cooperation: Ecological regions of North America: Toward a common perspective, Published by the Communications and Public Outreach Department of the CEC Secretariat, Montreal, Quebec, Canada, 71 pp., ISBN 2-922305-18-X, 1997.

Chapin, F. S., Callaghan, T. V., Bergeron, Y., Fukuda, M., Johnstone, J. F., Juday, G., and Zimov, S. A.: Global change and the boreal forest: Thresholds, shifting states or gradual change?, Ambio, 33, 361-365, https://doi.org/10.1579/0044-7447-33.6.361, 2004.

Christensen, C. W., Hayashi, M., and Bentley, L. R.: Hydrogeological characterization of an alpine aquifer system in the Canadian Rocky Mountains, Hydrogeol. J., 28, 1871-1890, https://doi.org/10.1007/s10040-020-02153-7, 2020.

Clarke, G. K., Jarosch, A. H., Anslow, F. S., Radić, V., and Menounos, B.: Projected deglaciation of western Canada in the twenty-first century, Nat. Geosci., 8, 372-377, https://doi.org/10.1038/ngeo2407, 2015.

Coles, A. E. and McDonnell, J. J.: Fill and spill drives runoff connectivity over frozen ground, J. Hydrol., 558, 115-128, https://doi.org/10.1016/j.jhydrol.2018.01.016, 2018.

Coles, A. E., McConkey, B. G., and McDonnell, J. J.: Climate change impacts on hillslope runoff on the northern Great Plains, 1962-2013, J. Hydrol., 550, 538-548, https://doi.org/10.1016/j.jhydrol.2017.05.023, 2017.

Connon, R., Devoie, E., Hayashi, M., Veness, T., and Quinton, W.: The influence of shallow taliks on permafrost thaw and active layer dynamics in subarctic Canada, J. Geophys. Res., 123, 281297, https://doi.org/10.1002/2017JF004469, 2018.

Connon, R. F., Quinton, W. L., Craig, J. R., and Hayashi, M.: Changing hydrologic connectivity due to permafrost thaw in the lower Liard River valley, NWT, Canada, Hydrol. Process., 28, 4163-4178, https://doi.org/10.1002/hyp.10206, 2014.

Council of Canadian Academies: The sustainable management of groundwater in Canada, Report of the Expert Panel on Groundwater, Council of Canadian Academies, Ottawa, Canada, 255 pp., 2009.

Council of Canadian Academies: Water and agriculture in Canada: Towards sustainable management of water resources, Report of the Expert Panel on Sustainable Management of Water in the Agricultural Landscapes of Canada, Council of Canadian Academies, Ottawa, Canada, 259 pp., 2013.

Cuffey, K. and Paterson, W. S. B.: The Physics of Glaciers, in: Encyclopedia of the World's Biomes, 4th Edn., edited by: Goldstein, M. I. and DellaSala, A. A., Elsevier, 182-194, https://doi.org/10.1016/B978-0-12-409548-9.12441-8, 2010.

Cummings, D. I., Russell, H. A., and Sharpe, D. R.: Buriedvalley aquifers in the Canadian Prairies: Geology, hydrogeology, and origin, Can. J. Earth Sci., 49, 987-1004, https://doi.org/10.1139/e2012-041, 2012.

Davis, E. L. and Gedalof, Z. E.: Limited prospects for future alpine treeline advance in the Canadian Rocky Mountains, Global Change Biol., 24, 4489-4504, https://doi.org/10.1111/gcb.14338, 2018.

Davis, K. T., Dobrowski, S. Z., Holden, Z. A., Higuera, P. E., and Abatzoglou, J. T.: Microclimatic buffering in forests of the 
future: the role of local water balance, Ecography, 42, 1-11, https://doi.org/10.1111/ecog.03836, 2019.

Dearborn, K. D. and Danby, R., K.: Climatic drivers of tree growth at tree line in Southwest Yukon change over time and vary between landscapes, Climatic Change, 150, 211-225, https://doi.org/10.1007/s10584-018-2268-1, 2018.

DeBeer, C., Helgason, W. D., and Marsh, P. (Eds.): Water, ecosystem, cryosphere, and climate data from the interior of Western Canada and other cold regions, Earth Syst. Sci. Data, available at: https://essd.copernicus.org/articles/special_ issue901.html, last access: 6 April 2021.

DeBeer, C. M., Wheater, H. S., Quinton, W. L., Carey, S. K., Stewart, R. E., Mackay, M. D., and Marsh, P.: The Changing Cold Regions Network: Observation, diagnosis and prediction of environmental change in the Saskatchewan and Mackenzie River Basins, Canada, Sci. China Earth Sci., 58, 46-60, https://doi.org/10.1007/s11430-014-5001-6, 2015.

DeBeer, C. M., Wheater, H. S., Carey, S. K., and Chun, K. P.: Recent climatic, cryospheric, and hydrological changes over the interior of western Canada: a review and synthesis, Hydrol. Earth Syst. Sci., 20, 1573-1598, https://doi.org/10.5194/hess-20-1573-2016, 2016.

DeBeer, C. M. and Pomeroy, J. W.: Influence of snowpack and melt energy heterogeneity on snow cover depletion and snowmelt runoff simulation in a cold mountain environment, J. Hydrol., 553, 199-213, https://doi.org/10.1016/j.jhydrol.2017.07.051, 2017.

DeBeer, C. M., Sharp, M., and Schuster-Wallace, C.: Glaciers and Ice Sheets, in: Encyclopedia of the World's Biomes, 4, edited by: Goldstein, M. I. and DellaSala, D. A., Elsevier, 182-194, https://doi.org/10.1016/B978-0-12-409548-9.12441-8, 2020.

Dee, D. P., Uppala, S. M., Simmons, A. J., Berrisford, P., Poli, P., Kobayashi, S., Andrae, U., Balmaseda, M. A., Balsamo, G., Bauer, P., Bechtold, P., Beljaars, A. C., van de Berg, L., Bidlot, J., Bormann, N., Delsol, C., Dragani, R., Fuentes, M., Geer, A. J., Haimberger, L., Healy, S. B., Hersbach, H., Hólm, E. V., Isaksen, L., Kållberg, P., Köhler, M., Matricardi, M., McNally, A. P., Monge-Sanz, B. M., Morcrette, J., Park, B., Peubey, C., de Rosnay, P., Tavolato, C., Thépaut, J., and Vitart, F.: The ERAInterim reanalysis: configuration and performance of the data assimilation system, Q. J. Roy. Meteorol. Soc., 137, 553-597, https://doi.org/10.1002/qj.828, 2011.

Demuth, M.: Glaciers, in: 2018 State of the Mountains Report, Vol. 1, edited by: Parrott, L., Robinson, Z., and Hik, D., Alpine Club of Canada, Canmore, Alberta, Canada, 25-27, ISBN 9780-920330-71-5, 2018.

Demuth, M. N. and Ednie, M.: A glacier condition and thresholding rubric for use in assessing protected area/ecosystem functioning, Open File 8031, Geological Survey of Canada, Ottawa, Ontario, Canada, 53 pp., https://doi.org/10.4095/297892, 2016.

Demuth, M. N. and Horne, G.: Decadal-centenary glacier mass changes and their variability, Jasper National Park of Canada, Alberta, including the Columbia Icefield region, Open File 8229, Geological Survey of Canada, Ottawa, Ontario, Canada, https://doi.org/10.4095/304236, 2017.

Demuth, M. N., Pinard, V., Pientroniro, A., Luckman, B., Hopkinson, C., Dornes, P., and Comeau, L.: Recent and past-century variations in the glacier resources of the Canadian Rocky Mountains - Nelson River system, Terra Glacialis, 11, 27-52, 2008.
Demuth, M. N., Wilson, P., and Haggarty, D.: Glaciers of the Ragged Range, Nahanni National Park Reserve, Northwest Territories, Canada, in: Global Land Ice Measurements from Space, Springer Praxis Books, edited by: Kargel, J., Leonard, G., Bishop, M., Kääb, A., and Raup, B., Springer, Berlin, Heidelberg, https://doi.org/10.1007/978-3-540-79818-7_16, 2014.

Devito, K. J., Hokanson, K. J., Moore, P. A., Kettridge, N., Anderson, A. E., Chasmer, L., Hopkinson, C., Lukenbach, M. C., Mendoza, C. A., Morissette, J., Peters, D. L., Petrone, R. M., Silins, U., Smerdon, B., and Waddington, J. M.: Landscape controls on long-term runoff in subhumid heterogeneous Boreal Plains catchments, Hydrol. Process., 31, 2737-2751, https://doi.org/10.1002/hyp.11213, 2017.

Devoie, É. G., Craig, J. R., Connon, R. F., and Quinton, W. L.: Taliks: A tipping point in discontinuous permafrost degradation in peatlands, Water Resour. Res., 55, 9838-9857, https://doi.org/10.1029/2018WR024488, 2019.

Dirmeyer, P. A., Schlosser, C. A., and Brubaker, K. L.: Precipitation, recycling, and land memory: An integrated analysis, J. Hydrometeorol., 10, 278-288, https://doi.org/10.1175/2008JHM1016.1, 2009.

Dumanski, S., Pomeroy, J. W., and Westbrook, C. J.: Hydrological regime changes in a Canadian Prairie basin, Hydrol. Process., 29, 3893-3904, https://doi.org/10.1002/hyp.10567, 2015.

Ednie, M. and Demuth, M. N.: Contemporary glacier area changes in the Ragged Range, Northwest Territories, including Nahanni National Park Reserve of Canada, Open File 8401, Geological Survey of Canada, Ottawa, Ontario, Canada, https://doi.org/10.4095/311351, 2018.

Ellis, C. R., Pomeroy, J. W., Brown, T., and MacDonald, J.: Simulation of snow accumulation and melt in needleleaf forest environments, Hydrol. Earth Syst. Sci., 14, 925-940, https://doi.org/10.5194/hess-14-925-2010, 2010.

Elshamy, M. E., Princz, D., Sapriza-Azuri, G., Abdelhamed, M. S., Pietroniro, A., Wheater, H. S., and Razavi, S.: On the configuration and initialization of a large-scale hydrological land surface model to represent permafrost, Hydrol. Earth Syst. Sci., 24, 349 379, https://doi.org/10.5194/hess-24-349-2020, 2020.

Ensom, T., Makarieva, O., Morse, P., Kane, D., Alekseev, V., and Marsh, P.: The distribution and dynamics of aufeis in permafrost regions, Permafrost Periglac., 31, 383-395, https://doi.org/10.1002/ppp.2051, 2020.

Fang, X. and Pomeroy, J. W.: Diagnosis of future changes in hydrology for a Canadian Rockies headwater basin, Hydrol. Earth Syst. Sci., 24, 2731-2754, https://doi.org/10.5194/hess-24-27312020, 2020.

Fang, X., Pomeroy, J. W., Ellis, C. R., MacDonald, M. K., DeBeer, C. M., and Brown, T.: Multi-variable evaluation of hydrological model predictions for a headwater basin in the Canadian Rocky Mountains, Hydrol. Earth Syst. Sci., 17, 1635-1659, https://doi.org/10.5194/hess-17-1635-2013, 2013.

Fortin, V., Roy, G., Stadnyk, T., Koenig, K., Gasset, N., and Mahidjiba, A.: Ten years of science based on the Canadian precipitation analysis: A CaPA system overview and literature review, Atmos.-Ocean, 56, 178-196, https://doi.org/10.1080/07055900.2018.1474728, 2018.

Gibson, C., Morse, P. D., Kelly, J. M., Turetsky, M. R., Baltzer, J. L., Gingras-Hill, T., and Kokelj, S. V.: Thermokarst Mapping Collective: Protocol for organic permafrost terrain and preliminary 
inventory from the Taiga Plains test area, Northwest Territories, appendix, and digital data, NWT Open Report 2020-010, Northwest Territories Geological Survey, Yellowknife, Northwest Territories, Canada, 24 pp., 2020.

Gibson, C. M., Chasmer, L. E., Thompson, D. K., Quinton, W. L., Flannigan, M. D., and Olefeldt, D.: Wildfire as a major driver of recent permafrost thaw in boreal peatlands, Nat. Commun., 9, 3041, https://doi.org/10.1038/s41467-018-05457-1, 2018.

GNWT - Government of the Northwest Territories: Mountain pine beetle vulnerability (Pan-Territorial Information Notes No. Mar.2013.NT.05), Forest Management Division, Department of Environment and Natural Resources, Government of Northwest Territories, Fort Smith, NT, 2013.

Gober, P. and Wheater, H. S.: Socio-hydrology and the science-policy interface: A case study of the Saskatchewan River basin, Hydrol. Earth Syst. Sci., 18, 1413-1422, https://doi.org/10.5194/hess-18-1413-2014, 2014.

Granger, R. and Pomeroy, J. W.: Sustainability of the western Canadian boreal forest under changing hydrological conditions. II. Summer energy and water use, in: Sustainability of Water Resources Under Increasing Uncertainty (Proceedings of the Rabat Symposium S1, April 1997), IAHS Publ., 240, 243-249, 1997.

Grünberg, I., Wilcox, E. J., Zwieback, S., Marsh, P., and Boike, J.: Linking tundra vegetation, snow, soil temperature, and permafrost, Biogeosciences, 17, 4261-4279, https://doi.org/10.5194/bg-17-4261-2020, 2020.

GWF - Global Water Futures: Solutions to Water Threats in an Era of Global Change, available at: https://gwf.usask.ca/, last access: 6 April 2021.

Hanes, C. C., Wang, X., Jain, P., Parisien, M.-A., Little, J. M., and Flannigan, M. D.: Fire-regime changes in Canada over the last half century, Can. J. Forest Res., 49, 256-269, https://doi.org/10.1139/cjfr-2018-0293, 2019.

Hanesiak, J., Stewart, R. E., Bonsal, B. R., Harder, P., Lawford, R., Aider, R., Amiro, B. D., Atallah, E., Barr, A. G., Black, T. A., Bullock, P., Brimelow, J. C., Brown, R., Carmichael, H., Derksen, C., Flanagan, L. B., Gachon, P., Greene, H., Gyakum, J., Henson, W., Hogg, E. H., Kochtubajda, B., Leighton, H., Lin, C., Luo, Y., McCaughey, J. H., Meinert, A., Shabbar, A., Snelgrove, K., Szeto, K., Trishchenko, A., van der Kamp, G., Wang, S., Wen, L., Wheaton, E., Wielki, C., Yang, Y., Yirdaw, S., and Zha, T.: Characterization and summary of the 19992005 Canadian Prairie drought, Atmos.-Ocean, 49, 421-452, https://doi.org/10.1080/07055900.2011.626757, 2011.

Hannah, L., Roehrdanz, P. R., KC, K. B., Fraser, E. D., Donatti, C. I.,Saenz, L., Wright, T. M., Hijmans, R. J., Mulligan, M., Berg, A., and van Soesbergen, A.: The environmental consequences of climate-driven agricultural frontiers, PloS ONE, 15, e0228305, https://doi.org/10.1371/journal.pone.0228305, 2020.

Harder, P. and Pomeroy, J. W.: Hydrological model uncertainty due to precipitation-phase partitioning methods, Hydrol. Process., 28, 4311-4327, https://doi.org/10.1002/hyp.10214, 2014.

Harder, P., Pomeroy, J. W., and Helgason, W. D.: Implications of stubble management on snow hydrology and meltwater partitioning, Can. Water Resour. J., 44, 193-204, https://doi.org/10.1080/07011784.2019.1575774, 2019.

Harrington, J. S., Mozil, A., Hayashi, M., and Bentley, L. R.: Groundwater flow and storage processes in an inactive rock glacier, Hydrol. Process., 32, 3070-3088, https://doi.org/10.1002/hyp.13248, 2018.

Harsch, M. A., Hulme, P. E., McGlone, M. S., and Duncan, R. P.: Are treelines advancing? A global meta-analysis of treeline response to climate warming, Ecol. Lett., 12, 1040-1049, https://doi.org/10.1111/j.1461-0248.2009.01355.x, 2009.

Hart, S. J., Henkelman, J., McLoughlin, P. D., Nielsen, S. E., Truchon-Savard, A., and Johnstone, J. F.: Examining forest resilience to changing fire frequency in a fire-prone region of boreal forest, Global Change Biol., 25, 869-884, https://doi.org/10.1111/gcb.14550, 2019.

Hayashi, M.: Alpine hydrogeology: The critical role of groundwater in sourcing the headwaters of the world, Groundwater, 58:, 498510, https://doi.org/10.1111/gwat.12965, 2020.

Hayashi, M. and Farrow, C. R.: Watershed-scale response of groundwater recharge to inter-annual and inter-decadal variability in precipitation, Hydrogeol. J., 22, 1825-1839, https://doi.org/10.1007/s10040-014-1176-3, 2014.

Hayashi, M., van der Kamp, G., and Rosenberry, D. O.: Hydrology of prairie wetlands: Understanding the integrated surfacewater and groundwater processes, Wetlands, 36, 237-254, https://doi.org/10.1007/s13157-016-0797-9, 2016.

Haynes, K. M., Connon, R. F., and Quinton, W. L.: Permafrost thaw induced drying of wetlands at Scotty Creek, NWT, Canada, Environ. Res. Lett., 13, 114001, https://doi.org/10.1088/17489326/aae46c, 2018.

Hedstrom, N. R. and Pomeroy, J. W.: Measurements and modelling of snow interception in the boreal forest, Hydrol. Process., 12, 1611-1625, https://doi.org/10.1002/(SICI)10991085(199808/09)12:10/11<1611::AID-HYP684>3.0.CO;2-4, 1998.

Helbig, M., Pappas, C., and Sonnentag, O.: Permafrost thaw and wildfire: Equally important drivers of boreal tree cover changes in the Taiga Plains, Canada, Geophys. Res. Lett., 43, 1598-1606, https://doi.org/10.1002/2015GL067193, 2016.

Hogg, E. H., Brandt, J. P., and Michaelian, M.: Impacts of a regional drought on the productivity, dieback, and biomass of western Canadian aspen forests, Can. J. Forest Res., 38, 1373-1384, https://doi.org/10.1139/X08-001, 2008.

Holloway, J. E., Lewkowicz, A. G., Douglas, T. A., Li, X., Turetsky, M. R., Baltzer, J. L., and Jin, H.: Impact of wildfire on permafrost landscapes: A review of recent advances and future prospects, Permafrost Periglac. Process., 31, 371-382, https://doi.org/10.1002/ppp.2048, 2020.

Hood, J. L. and Hayashi, M.: Characterization of snowmelt flux and groundwater storage in an alpine headwater basin, J. Hydrol., 521, 482-497, https://doi.org/10.1016/j.jhydrol.2014.12.041, 2015.

Huss, M. and Hock, R.: Global-scale hydrological response to future glacier mass loss, Nat. Clim. Change, 8, 135-140, https://doi.org/10.1038/s41558-017-0049-x, 2018.

IPCC - Intergovernmental Panel on Climate Change: Climate Change 2013: The Physical Science Basis, in: Contribution of Working Group I to the Fifth Assessment Report of the Intergovernmental Panel on Climate Change, edited by: Stocker, T. F., Qin, D., Plattner, G.-K., Tignor, M., Allen, S. K., Boschung, J., Nauels, A., Xia, Y., Bex, V., and Midgley, P. M., Cambridge University Press, Cambridge, UK and New York, NY, USA, 1535 pp., 2013. 
Ireson, A. M., Barr, A. G., Johnstone, J. F., Mamet, S. D., Van der Kamp, G., Whitfield, C. J., Michel, N. L., North, R. L., Westbrook, C. J., DeBeer, C., Chun, K. P., Nazemi, A., and Sagin, J.: The changing water cycle: the Boreal Plains ecozone of Western Canada, Wiley Interdisciplin. Rev.: Water, 2, 505-521, https://doi.org/10.1002/wat2.1098, 2015.

Johnstone, J. F., Hollingsworth, T. N., Chapin, F. S., and Mack, M. C.: Changes in fire regime break the legacy lock on successional trajectories in Alaskan boreal forest, Global Change Biol., 16, 1281-1295, https://doi.org/10.1111/j.1365-2486.2009.02051.x, 2010a.

Johnstone, J. F., McIntire, E. J. B., Pedersen, E., King, G., and Pisaric, M. F. J.: A sensitive slope: Estimating landscape patterns of forest resilience in a changing climate, Ecosphere, 1, 14, https://doi.org/10.1890/ES10-00102.1, 2010b.

Johnstone, J. F., Chapin, F. S., Hollingsworth, T. N., Mack, M. C., Romanovsky, V., and Turetsky, M.: Fire, climate change, and forest resilience in interior Alaska, Can. J. Forest Res., 40, 13021312, https://doi.org/10.1139/X10-061, 2010c.

Johnstone, J. F., Allen, C. D., Franklin, J. F., Frelich, L. E., Harvey, B. D., Higuera, P. E., Mack, M. C., Meentemeyer, R. K., Metz, M. R., Perry, G. L. W., Schoennagel, T., and Turner, M. G.: Changing disturbance regimes, ecological memory, and forest resilience, Front. Ecol. Environ., 14, 369-378, https://doi.org/10.1002/fee.1311, 2016.

Ju, J. and Masek, J. G.: The vegetation greenness trend in Canada and US Alaska from 1984-2012 Landsat data, Remote Sens. Environ., 176, 1-16, https://doi.org/10.1016/j.rse.2016.01.001, 2016.

Keane, R. E., Hessburg, P. F., Landres, P. B., and Swanson, F. J.: The use of historical range and variability (HRV) in landscape management, Forest Ecol. Manage., 258, 1025-1037, https://doi.org/10.1016/j.foreco.2009.05.035, 2009.

Keenan, T. F. and Riley, W. J.: Greening of the land surface in the world's cold regions consistent with recent warming, Nat. Clim. Change, 8, 825-828, https://doi.org/10.1038/s41558-018-0258y, 2018.

Kljun, N., Black, T. A., Griffis, T. J., Barr, A. G., GaumontGuay, D., Morgenstern, K., McCaughey, J. H., and Nesic, Z.: Response of net ecosystem productivity of three boreal forest stands to drought, Ecosystems, 9, 1128-1144, https://doi.org/10.1007/s10021-005-0082-x, 2006.

Krogh, S. A. and Pomeroy, J. W.: Impact of Future Climate and Vegetation on the Hydrology of an Arctic Headwater Basin at the Tundra-Taiga Transition, J. Hydrometeorol., 20, 197-215, https://doi.org/10.1175/JHM-D-18-0187.1, 2019.

Krogh, S. A., Pomeroy, J. W., and Marsh, P.: Diagnosis of the hydrology of a small Arctic basin at the tundra-taiga transition using a physically based hydrological model, J. Hydrol., 550, 685703, https://doi.org/10.1016/j.jhydrol.2017.05.042, 2017.

Kurkute, S., Li, Z., Li, Y., and Huo, F.: Assessment and projection of the water budget over western Canada using convectionpermitting weather research and forecasting simulations, Hydrol. Earth Syst. Sci., 24, 3677-3697, https://doi.org/10.5194/hess-243677-2020, 2020.

Kurylyk, B. L., Hayashi, M., Quinton, W. L., McKenzie, J. M., and Voss, C. I.: Influence of vertical and lateral heat transfer on permafrost thaw, peatland landscape transition, and groundwater flow, Water Resour. Res., 52, 1286-1305, https://doi.org/10.1002/2015WR018057, 2016.

Landhausser, S. M., Deshaies, D., and Lieffers, V. J.: Disturbance facilitates rapid range expansion of aspen into higher elevations of the Rocky Mountains under a warming climate, J. Biogeogr., 37, 68-76, https://doi.org/10.1111/j.13652699.2009.02182.x, 2010.

Lantz, T. C., Kokelj, S. V., Gergel, S. E., and Henryz, G. H. R.: Relative impacts of disturbance and temperature: Persistent changes in microenvironment and vegetation in retrogressive thaw slumps, Global Change Biol., 15, 1664-1675, https://doi.org/10.1111/j.1365-2486.2009.01917.x, 2009.

Lantz, T. C., Marsh, P., and Kokelj, S. V.: Recent Shrub Proliferation in the Mackenzie Delta Uplands and Microclimatic Implications, Ecosystems, 16, 47-59, https://doi.org/10.1007/s10021012-9595-2, 2013.

Lantz, T. C., Moffat, N. D., Fraser, R. H., and Walker, X.: Reproductive limitation mediates the response of white spruce (Picea glauca) to climate warming across the forest-tundra ecotone, Arctic Sci., 5, 167-184, https://doi.org/10.1139/as-2018-0012, 2019.

Lara, R. P., Berg, A. A., Warland, J., and Tetlock, E.: In situ estimates of freezing/melting point depression in agricultural soils using permittivity and temperature measurements, Water Resour. Res., 56, e2019WR026020, https://doi.org/10.1029/2019WR026020, 2020.

Leroux, N. R. and Pomeroy, J. W.: Modelling capillary hysteresis effects on preferential flow through melting and cold layered snowpacks, Adv. Water Resour., 107, 250-264, https://doi.org/10.1016/j.advwatres.2017.06.024, 2017.

Leroux, N. R. and Pomeroy, J. W.: Simulation of capillary pressure overshoot in snow combining trapping of the wetting phase with a nonequilibrium Richards equation model, Water Resour. Res., 55, 236-248, https://doi.org/10.1029/2018WR022969, 2019.

Lewkowicz, A. G. and Way, R. G.: Extremes of summer climate trigger thousands of thermokarst landslides in a High Arctic environment, Nat. Commun., 10, 1329, https://doi.org/10.1038/s41467-019-09314-7, 2019.

Li, L. and Pomeroy, J. W.: Probability of occurrence of blowing snow, J. Geophys. Res., 102, 21955-21964, https://doi.org/10.1029/97JD01522, 1997.

Li, Y., Szeto, K., Stewart, R. E., Thériault, J. M., Chen, L., Kochtubajda, B., Liu, A., Boodoo, S., Goodson, R., Mooney, C., and Kurkute, S.: A numerical study of the June 2013 floodproducing extreme rainstorm over southern Alberta, J. Hydrometeorol., 18, 2057-2078, https://doi.org/10.1175/JHM-D15-0176.1, 2017.

Li, Y., Li, Z., Zhang, Z., Chen, L., Kurkute, S., Scaff, L., and Pan, X.: High-resolution regional climate modeling and projection over western Canada using a weather research forecasting model with a pseudo-global warming approach, Hydrol. Earth Syst. Sci., 23, 4635-4659, https://doi.org/10.5194/hess-23-46352019, 2019.

Lund, M.: Uncovering the unknown - climate interactions in a changing arctic tundra, Environ. Res. Lett., 13, 061001, https://doi.org/10.1088/1748-9326/aac63f, 2018.

Lundquist, J. D., Dickerson-Lange, S. E., Lutz, J. A., and Cristea, N. C.: Lower forest density enhances snow retention in regions with warmer winters: A global framework developed from plot-scale 
observations and modeling, Water Resour. Res., 49, 6356-6370, https://doi.org/10.1002/wrcr.20504, 2013.

Macias-Fauria, M. and Johnson, E. A.: Warming-induced upslope advance of subalpine forest is severely limited by geomorphic processes, P. Natl. Acad. Sci. USA, 110, 8117-8122, https://doi.org/10.1073/pnas.1221278110, 2013.

Mack, M. C., Bret-Harte, M. S., Hollingsworth, T. N., Jandt, R. R., Schuur, E. A. G., Shaver, G. R., and Verbyla, D. L.: Carbon loss from an unprecedented Arctic tundra wildfire, Nature, 475, 489492, https://doi.org/10.1038/nature10283, 2011.

Mamet, S. D., Brown, C. D., Trant, A. J., and Laroque, C. P.: Shifting global Larix distributions: Northern expansion and southern retraction as species respond to changing climate, J. Biogeogr., 46, 30-44, https://doi.org/10.1111/jbi.13465, 2019.

Margolis, H. A., and Ryan, M. G.: A physiological basis for biosphere-atmosphere interactions in the boreal forest: An overview, Tree Physiol., 17, 491-499, https://doi.org/10.1093/treephys/17.8-9.491, 1997.

Marsh, P., Mann, P., and Walker, B.: Changing snowfall and snow cover in the western Canadian Arctic, in: 22nd Northern Research Basins Symposium and Workshop, edited by: Quinton, W., 1-10, available at: https://conferences.wlu.ca/22ndnrb/ (last access: 6 April 2021), 2019.

Marshall, S. J. and Miller, K.: Seasonal and interannual variability of melt-season albedo at Haig Glacier, Canadian Rocky Mountains, The Cryosphere, 14, 1-19, https://doi.org/10.5194/tc-14-12020, 2020.

Marshall, S. J., White, E. C., Demuth, M. N., Bolch, T., Wheate, R., Menounos, B., Beedle, M. J., and Shea, J. M.: Glacier water resources on the eastern slopes of the Canadian Rocky Mountains, Can. Water Resour. J., 36, 109-134, https://doi.org/10.4296/cwrj3602823, 2011.

Martz, L. W., Bruneau, J., and Rolfe, J. T.: Climate change and water: SSRB (South Saskatchewan River Basin) final technical report, University of Saskatchewan, Saskatoon, SK, Canada, 341 pp., 2007.

Marzeion, B., Kaser, G., Maussion, F., and Champollion, N.: Limited influence of climate change mitigation on shortterm glacier mass loss, Nat. Clim. Change, 8, 305-308, https://doi.org/10.1038/s41558-018-0093-1, 2018.

Mekis, E., Stewart, R. E., Theriault, J. M., Kochtubajda, B., Bonsal, B. R., and Liu, Z.: Near- $0{ }^{\circ} \mathrm{C}$ surface temperature and precipitation type patterns across Canada, Hydrol. Earth Syst. Sci., 24, 1741-1761, https://doi.org/10.5194/hess-24-1741-2020, 2020.

Mekonnen, M. A., Wheater, H. S., Ireson, A. M., Spence, C., Davison, B., and Pietroniro, A.: Towards an improved land surface scheme for prairie landscapes, J. Hydrol., 511, 105-116, https://doi.org/10.1016/j.jhydrol.2014.01.020, 2014.

Ménard, C. B., Essery, R., and Pomeroy, J.: Modelled sensitivity of the snow regime to topography, shrub fraction and shrub height, Hydrol. Earth Syst. Sci., 18, 2375-2392, https://doi.org/10.5194/hess-18-2375-2014, 2014.

Menounos, B., Hugonnet, R., Shean, D., Gardner, A., Howat, I., Berthier, E., Pelto, B., Tennant, C., Shea, J., Noh, M.-J., Brun, F., and Dehecq, A.: Heterogeneous changes in western North American glaciers linked to decadal variability in zonal wind strength, Geophys. Res. Lett., 46, 200-209 https://doi.org/10.1029/2018GL080942, 2019.
Moore, R. D., Pelto, B., Menounos, B., and Hutchinson, D.: Detecting the Effects of Sustained Glacier Wastage on Streamflow in Variably Glacierized Catchments, Front. Earth Sci., 8, 136, https://doi.org/10.3389/feart.2020.00136, 2020.

Mortsch, L., Cohen, S., and Koshida, G.: Climate and water availability indicators in Canada: Challenges and a way forward. Part II - Historic trends, Can. Water Resour. J., 40, 146-159, https://doi.org/10.1080/07011784.2015.1006024, 2015.

Mudryk, L. R., Derksen, C., Howell, S., Laliberté, F., Thackeray, C., Sospedra-Alfonso, R., Vionnet, V., Kushner, P. J., and Brown, R.: Canadian snow and sea ice: historical trends and projections, The Cryosphere, 12, 1157-1176, https://doi.org/10.5194/tc-12-11572018, 2018.

Munroe, E. A.: Effects of aquifer heterogeneity on estimation of permissible long-term groundwater extraction rates, MSc Thesis, University of Calgary, Calgary, AB, Canada, 141 pp., 2015.

Musselman, K. N., Clark, M. P., Liu, C., Ikeda, K., and Rasmussen, R.: Slower snowmelt in a warmer world, Nat. Clim. Change, 7, 214-219, https://doi.org/10.1038/nclimate3225, 2017.

Myers-Smith, I. H., Forbes, B. C., Wilmking, M., Hallinger, M., Lantz, T., Blok, D., Tape, K. D., Macias-Fauria, M., SassKlaassen, U., Lévesque, E., Boudreau, S., Ropars, P., Hermanutz, L., Trant, A., Siegwart Collier, L., Weijers, S., Rozema, J., Rayback, S. A., Schmidt, N. M., Schaepman-Strub, G., Wipf, S., Rixen, C., Ménard, C. B., Venn, S., Goetz, S., Andreu-Hayles, L., Elmendorf, S., Ravolainen, V., Welker, J., Grogan, P., Epstein, H. E., and Hik, D. S.: Shrub expansion in tundra ecosystems: Dynamics, impacts and research priorities, Environ. Res. Lett., 6, 045509, https://doi.org/10.1088/1748-9326/6/4/045509, 2011.

Myers-Smith, I. H., Grabowski, M. M., Thomas, H. J. D., AngersBlondin, S., Daskalova, G. N., Bjorkman, A. D., Cunliffe, A. M., Assmann, J. J., Boyle, J. S., McLeod, E., McLeod, S., Joe, R., Lennie, P., Arey, D., Gordon, R. R., and Eckert, C. D.: Eighteen years of ecological monitoring reveals multiple lines of evidence for tundra vegetation change, Ecol. Monogr., 89, e01351, https://doi.org/10.1002/ecm.1351, 2019.

Nazarbakhsh, M., Ireson, A. M., and Barr, A. G.: Controls on evapotranspiration from jack pine forests in the Boreal Plains Ecozone, Hydrol. Process., 34, 927-940, https://doi.org/10.1002/hyp.13674, 2020.

Olefeldt, D., Goswami, S., Grosse, G., Hayes, D., Hugelius, G., Kuhry, P., McGuire, A. D., Romanovsky, V. E., Sannel, A. B. K., Schuur, E. A. G., and Turetsky, M. R.: Circumpolar distribution and carbon storage of thermokarst landscapes, Nat. Commun., 7, 1-11, https://doi.org/10.1038/ncomms13043, 2016.

Patankar, R., Quinton, W. L., Hayashi, M., and Baltzer, J. L.: Sap flow responses to seasonal thaw and permafrost degradation in a subarctic boreal peatland, Trees, 29, 129-142, https://doi.org/10.1007/s00468-014-1097-8, 2015.

Pavlovskii, I., Hayashi, M., and Itenfisu, D.: Midwinter melts in the Canadian prairies: energy balance and hydrological effects, Hydrol. Earth Syst. Sci., 23, 1867-1883, https://doi.org/10.5194/hess-23-1867-2019, 2019.

Paznekas, A. and Hayashi, M.: Groundwater contribution to winter streamflow in the Canadian Rockies, Can. Water Resour. J., 41, 484-499, https://doi.org/10.1080/07011784.2015.1060870, 2016.

Peach, D. and Wheater, H.: Groundwater, hydrogeology and sustainability in Saskatchewan: A review of groundwater and hy- 
drogeological issues for Saskatchewan and the development of a research strategy, Global Institute for Water Security internal report, University of Saskatchewan, Saskatoon, Canada, 54 pp., 2014.

Pelto, B. M., Menounos, B., and Marshall, S. J.: Multi-year evaluation of airborne geodetic surveys to estimate seasonal mass balance, Columbia and Rocky Mountains, Canada, The Cryosphere, 13, 1709-1727, https://doi.org/10.5194/tc-13-1709-2019, 2019.

Peng, C., Ma, Z., Lei, X., Zhu, Q., Chen, H., Wang, W., Liu, S., Li, W., Fang, X., and Zhou, X.: A drought-induced pervasive increase in tree mortality across Canada's boreal forests, Nat. Clim. Change, 1, 467-471, https://doi.org/10.1038/nclimate1293, 2011.

Pietroniro, A., Fortin, V., Kouwen, N., Neal, C., Turcotte, R., Davison, B., Verseghy, D., Soulis, E. D., Caldwell, R., Evora, N., and Pellerin, P.: Development of the MESH modelling system for hydrological ensemble forecasting of the Laurentian Great Lakes at the regional scale, Hydrol. Earth Syst. Sci., 11, 1279-1294, https://doi.org/10.5194/hess-11-1279-2007, 2007.

Pinno, B. D., Errington, R. C., and Thompson, D. K.: Young jack pine and high severity fire combine to create potentially expansive areas of understocked forest, Forest Ecol. Manage., 310, 517-522, https://doi.org/10.1016/j.foreco.2013.08.055, 2013.

Pomeroy, J. W., de Boer, D., and Martz, L. M.: Hydrology and Water Resources of Saskatchewan, Centre for Hydrology Report No. 1, University of Saskatchewan, Saskatoon, SK, Canada, 25 pp., 2005.

Pomeroy, J. W., Bewley, D. S., Essery, R. L. H., Hedstrom, N. R., Link, T., Granger, R. J., Sicart, J.-E., Ellis, C. R., and Janowicz, J. R.: Shrub tundra snowmelt, Hydrol. Process., 20, 923-941, https://doi.org/10.1002/hyp.6124, 2006.

Pomeroy, J. W., Gray, D. M., Brown, T., Hedstrom, N. R., Quinton, W. L., Granger, R. J., and Carey, S. K.: The cold regions hydrological model: A platform for basing process representation and model structure on physical evidence, Hydrol. Process., 21, 2650-2667, https://doi.org/10.1002/hyp.6787, 2007.

Pomeroy, J. W., Fang, X., and Williams, B.: Impacts of climate change on Saskatchewan's water resources, Centre for Hydrology Report No. 6, University of Saskatchewan, Saskatoon, SK, Canada, 46 pp., 2009.

Pomeroy, J. W., Fang, X., and Ellis, C.: Sensitivity of snowmelt hydrology in Marmot Creek, Alberta, to forest cover disturbance, Hydrol. Process., 26, 1891-1904, https://doi.org/10.1002/hyp.9248, 2012.

Pomeroy, J. W., Shook, K., Fang, X., Dumanski, S., Westbrook, C., and Brown, T.: Improving and testing the prairie hydrological model at Smith Creek Research Basin, Centre for Hydrology Report No. 14, University of Saskatchewan, Saskatoon, SK, Canada, 102 pp., 2014.

Pomeroy, J. W., Fang, X., and Rasouli, K.: Sensitivity of snow processes to warming in the Canadian Rockies, in: Proceedings of the 72nd Eastern Snow Conference, 9-11 June 2015, Jouvence, Orford, Quebec, Canada, 22-33, 2015.

Post, E., Forchhammer, M. C., Bret-Harte, M. S., Callaghan, T. V., Christensen, T. R., Elberling, B., Fox, A. D., Gilg, O., Hik, D. S., Høye, T. T., Ims, R. A., Jeppesen, E., Klein, D. R., Madsen, J., McGuire, A. D., Rysgaard, S., Schindler, D. E., Stirling, I., Tamstorf, M. P., Tyler, N. J. C., van der Wal, R., Welker, J., Wookey, P. A., Schmidt, N. M., and Aastrup, P.: Ecological dynamics across the Arctic associated with recent climate change, Science, 325 , 1355-1358, https://doi.org/10.1126/science.1173113, 2009.

Pradhananga, D.: Response of Canadian Rockies glacier hydrology to changing climate, $\mathrm{PhD}$ thesis, University of Saskatchewan, Saskatoon, SK, Canada, 191 pp., 2020.

Pureswaran, D. S., De Grandpré, L., Paré, D., Taylor, A., Barrette, M., Morin, H., Régnière, J., and Kneeshaw, D. D.: Climateinduced changes in host tree-insect phenology may drive ecological state-shift in boreal forests, Ecology, 96, 1480-1491, https://doi.org/10.1890/13-2366.1, 2015.

Quinton, W., Berg, A., Braverman, M., Carpino, O., Chasmer, L., Connon, R., Craig, J., Devoie, É., Hayashi, M., Haynes, K., Olefeldt, D., Pietroniro, A., Rezanezhad, F., Schincariol, R., and Sonnentag, O.: A synthesis of three decades of hydrological research at Scotty Creek, NWT, Canada, Hydrol. Earth Syst. Sci., 23, 2015-2039, https://doi.org/10.5194/hess-23-2015-2019, 2019.

Quinton, W. L. and Baltzer, J. L.: The active-layer hydrology of a peat plateau with thawing permafrost (Scotty Creek, Canada), Hydrogeol. J., 21, 201-220, https://doi.org/10.1007/s10040-0120935-2, 2013.

Quinton, W. L., Hayashi, M., and Chasmer, L. E.: Peatland hydrology of discontinuous permafrost in the Northwest Territories: overview and synthesis, Can. Water Resour. J., 34, 311-328, https://doi.org/10.4296/cwrj3404311, 2009.

Rasmussen, R., Baker, B., Kochendorfer, J., Meyers, T., Landolt, S., Fischer, A. P., Black, J., Thériault, J. M., Kucera, P., Gochis, D., and Smith, C.: How well are we measuring snow: The NOAA/FAA/NCAR winter precipitation test bed, B. Am. Meteorol. Soc., 93, 811-829, https://doi.org/10.1175/BAMS-D-1100052.1, 2012.

Rasouli, K., Pomeroy, J. W., and Whitfield, P. H.: Are the effects of vegetation and soil changes as important as climate change impacts on hydrological processes?, Hydrol. Earth Syst. Sci., 23, 4933-4954, https://doi.org/10.5194/hess-23-4933-2019, 2019.

Razavi, S., Gober, P., Maier, H. R., Brouwer, R., and Wheater, H.: Anthropocene flooding: Challenges for science and society, Hydrol. Process., 34, 1996-2000, https://doi.org/10.1002/hyp.13723, 2020.

Rehfeldt, G. E., Crookston, N. L., Sáenz-Romero, C., and Campbell, E. M.: North American vegetation model for land-use planning in a changing climate: a solution to large classification problems, Ecol. Appl., 22, 119-141, https://doi.org/10.1890/110495.1, 2012.

RIFWP - Rosenberg International Forum on Water Policy: Rosenberg International Forum: The Mackenzie River Basin, Report of the Rosenberg International Forum's workshop on transboundary relations in the Mackenzie River Basin, 5-7 September 2012, Vancouver, British Columbia, Canada, 41 pp., 2013.

Rodell, M., Famiglietti, J. S., Wiese, D. N., Reager, J. T., Beaudoing, H. K., Landerer, F. W., and Lo, M.-H.: Emerging trends in global freshwater availability, Nature, 557, 651-659, https://doi.org/10.1038/s41586-018-0123-1, 2018.

Rogers, B. M., Balch, J. K., Goetz, S. J., Lehmann, C. E. R., and Turetsky, M.: Focus on changing fire regimes: interactions with climate, ecosystems, and society, Environ. Res. Lett., 15, 030201, https://doi.org/10.1088/1748-9326/ab6d3a, 2020.

Rouse, W. R., Blyth, E. M., Crawford, R. W., Gyakum, J. R., Janowicz, J. R., Kochtubajda, B., Leighton, H. G., Marsh, P., Martz, L., 
Pietroniro, A., Ritchie, H., Schertzer, W. M., Soulis, E. D., Stewart, R. E., Strong, G. S., and Woo, M. K.: Energy and water cycles in a high latitude, north-flowing river system: Summary of results from the Mackenzie GEWEX Study - Phase 1, B. Am. Meteorol. Soc., 84, 73-87, https://doi.org/10.1175/BAMS-84-1-73, 2003.

Roussin, D. M. and Binyamin, J.: Historical precipitation characteristics in the Palliser's Triangle region of the Canadian prairies, Prairie Perspect.: Geogr. Essays, 20, 36-48, 2018.

Rowlandson, T. L., Berg, A. A., Roy, A., Kim, E., Lara, R.P., Powers, J., Lewis, K., Houser, P., McDonald, K., Toose, P., and $\mathrm{Wu}$, A.: Capturing agricultural soil freeze/thaw state through remote sensing and ground observations: A soil freeze/thaw validation campaign, Remote Sens. Environ., 211, 59-70, https://doi.org/10.1016/j.rse.2018.04.003, 2018.

Samimi, S. and Marshall, S. J.: Diurnal cycles of meltwater percolation, refreezing, and drainage in the supraglacial snowpack of Haig Glacier, Canadian Rocky Mountains, Front. Earth Sci., 5, 1-15, https://doi.org/10.3389/feart.2017.00006, 2017.

Sapriza-Azuri, G., Gamazo, P., Razavi, S., and Wheater, H. S.: On the appropriate definition of soil profile configuration and initial conditions for land surface-hydrology models in cold regions, Hydrol. Earth Syst. Sci., 22, 3295-3309, https://doi.org/10.5194/hess-22-3295-2018, 2018.

Schirmer, M. and Pomeroy, J. W.: Processes governing snow ablation in alpine terrain - detailed measurements from the Canadian Rockies, Hydrol. Earth Syst. Sci., 24, 143-157, https://doi.org/10.5194/hess-24-143-2020, 2020.

Schuur, E. A. G. and Mack, M. C.: Ecological response to permafrost thaw and consequences for local and global ecosystem services, Annu. Rev. Ecol. Evol. S., 49, 279-301, https://doi.org/10.1146/annurev-ecolsys-121415-032349, 2018.

Segal, R. A., Lantz, T. C., and Kokelj, S. V.: Acceleration of thaw slump activity in glaciated landscapes of the Western Canadian Arctic, Environ. Res. Lett., 11, 034025, https://doi.org/10.1088/1748-9326/11/3/034025, 2016.

Seidl, R., Spies, T. A., Peterson, D. L., Stephens, S. L., and Hicke, J. A.: Searching for resilience: Addressing the impacts of changing disturbance regimes on forest ecosystem services, J. Appl. Ecol., 53, 120-129, https://doi.org/10.1111/1365-2664.12511, 2016.

Shi, X., Marsh, P., and Yang, D.: Warming spring air temperatures, but delayed spring streamflow in an Arctic headwater basin, Environ. Res. Lett., 10, 064003, https://doi.org/10.1088/17489326/10/6/064003, 2015.

Shook, K., Pomeroy, J., and van der Kamp, G.: The transformation of frequency distributions of winter precipitation to spring streamflow probabilities in cold regions; case studies from the Canadian Prairies, J. Hydrol., 521, 395-409, https://doi.org/10.1016/j.jhydrol.2014.12.014, 2015.

Smith, S. L.: Trends in permafrost conditions and ecology in northern Canada, Canadian Biodiversity: Ecosystem Status and Trends 2010, Technical Thematic Report No. 9, Canadian Councils of Resource Ministers, Ottawa, ON, iii + 22 pp., 2011.

Sniderhan, A., Mamet, S., and Baltzer, J.: Non-uniform growth dynamics of a dominant boreal tree species in the face of rapid climate change, Can. J. Forest Res., https://doi.org/10.1139/cjfr2020-0188, in press, 2020.

Sniderhan, A. E. and Baltzer, J. L.: Growth dynamics of black spruce (Picea mariana) in a rapidly thawing discontinuous per- mafrost peatland, J. Geophys. Res.-Biogeo., 121, 2988-3000, https://doi.org/10.1002/2016JG003528, 2016.

Spence, C. and Phillips, R. W.: Refining understanding of hydrological connectivity in a boreal catchment, Hydrol. Process., 29, 3491-3503, https://doi.org/10.1002/hyp.10270, 2015.

Stewart, R. E., Leighton, H. G., Marsh, P., Moore, G. W. K., Ritchie, H., Rouse, W. R., Soulis, E. D., Strong, G. S., Crawford, R. W., and Kochtubajda, B.: The Mackenzie GEWEX Study: The water and energy cycles of a major North American river basin, B. Am. Meteorol. Soc., 79, 2665-2683, https://doi.org/10.1175/15200477(1998)079<2665:TMGSTW>2.0.CO;2, 1998.

Stewart, R. E., Szeto, K. K., Bonsal, B. R., Hanesiak, J. M., Kochtubajda, B., Li, Y., Thériault, J. M., DeBeer, C. M., Tam, B. Y., Li, Z., Liu, Z., Bruneau, J. A., Duplessis, P., Marinier, S., and Matte, D.: Summary and synthesis of Changing Cold Regions Network (CCRN) research in the interior of western Canada Part 1: Projected climate and meteorology, Hydrol. Earth Syst. Sci., 23, 3437-3455, https://doi.org/10.5194/hess-23-3437-2019, 2019.

Stone, L. E., Fang, X., Haynes, K. M., Helbig, M., Pomeroy, J. W., Sonnentag, O., and Quinton, W. L.: Modelling the effects of permafrost loss on discharge from a wetland-dominated, discontinuous permafrost basin, Hydrol. Process., 33, 2607-2626, https://doi.org/10.1002/hyp.13546, 2019.

Stralberg, D., Arseneault, D., Baltzer, J. L., Barber, Q. E., Bayne, E. M., Boulanger, Y., Brown, C. D., Cooke, H. A., Devito, K., Edwards, J., Estevo, C. A., Flynn, N., Frelich, L. E., Hogg, E. H., Johnston, M., Logan, T., Matsuoka, S. M., Moore, P., Morelli, T. L., Morissette, J. L., Nelson, E. A., Nenzén, H., Nielsen, S. E., Parisien, M.-A., Pedlar, J. H., Price, D. T., Schmiegelow, F. K. A., Slattery, S. M., Sonnentag, O., Thompson, D. K., and Whitman, E.: Climate-change refugia in boreal North America: What, where, and for how long?, Front. Ecol. Environ., 18, 261-270, https://doi.org/10.1002/fee.2188, 2020.

Sulla-Menashe, D., Woodcock, C. E., and Friedl, M. A.: Canadian boreal forest greening and browning trends: An analysis of biogeographic patterns and the relative roles of disturbance versus climate drivers, Environ. Res. Lett., 13, 014007, https://doi.org/10.1088/1748-9326/aa9b88, 2018.

Szeto, K.: Assessing water and energy budgets for the Saskatchewan River Basin, J. Meteorol. Soc. Jpn. Ser. II, 85, 167-186, https://doi.org/10.2151/jmsj.85A.167, 2007.

Szeto, K., Gysbers, P., Brimelow, J., and Stewart, R.: The 2014 extreme flood on the southeastern Canadian Prairies, In: Explaining Extremes of 2014 from a Climate Perspective, B. Am. Meteorol. Soc., 96, S20-S24, 2015.

Szeto, K. S., Stewart, R. E., Yau, M. K., and Gyakum, J.: The Mackenzie climate system: A synthesis of MAGS atmospheric research, in: Cold Region Atmospheric and Hydrologic Studies. The Mackenzie GEWEX Experience, Vol. 1: Atmospheric Dynamics, edited by: Woo, M. K., Springer-Verlag, Berlin, Heidelberg, 23-50, 2008.

Tennant, C. and Menounos, B.: Glacier change of the Columbia Icefield, Canadian Rocky Mountains, 1919-2009, J. Glaciol., 59, 671-686, https://doi.org/10.3189/2013JoG12J135, 2013.

Tesemma, Z., Shook, K., and Pomeroy, J. W.: Diagnosis of Historical and Future Flow Regimes of the Bow River at Calgary Using a Dynamically Downscaled Climate Model and a Physically Based Land Surface Hydrological Model, Centre for Hy- 
drology Report No. 18, University of Saskatchewan, Saskatoon, Saskatchewan, Canada, 2020.

Toop, D. C. and de la Cruz, N. N.: Hydrogeology of the Canmore corridor and northwestern Kananaskis Country, Alberta, Alberta Environment, Hydrogeology Section, Edmonton, Alberta, Report to Western Economic Partnership Agreement, Western Economic Diversification Canada, Edmonton, Alberta, Canada, 2002.

Trant, A., Higgs, E., and Starzomski, B. M.: A century of high elevation ecosystem change in the Canadian Rocky Mountains, Sci. Rep., 10, 9698, https://doi.org/10.1038/s41598-020-662772, 2020.

Trenberth, K. E.: Atmospheric moisture recycling: Role of advection and local evaporation, J. Climate, 12, 1368-1381, https://doi.org/10.1175/15200442(1999)012<1368:AMRROA>2.0.CO;2, 1999.

Turetsky, M. R., Kane, E. S., Harden, J. W., Ottmar, R. D., Manies, K. L., Hoy, E., and Kasischke, E. S.: Recent acceleration of biomass burning and carbon losses in Alaskan forests and peatlands, Nat. Geosci., 4, 27-31, https://doi.org/10.1038/ngeo1027, 2011.

Turetsky, M. R., Baltzer, J. L., Johnstone, J. F., Mack, M. C., McCann, K. S., and Schuur, E. A. G.: Losing legacies, ecological release, and transient responses: Key challenges for the future of northern ecosystem science, Ecosystems, 20, 23-30, https://doi.org/10.1007/s10021-016-0055-2, 2017.

Turetsky, M. R., Abbott, B. W., Jones, M. C., Anthony, K. W., Olefeldt, D., Schuur, E. A. G., Koven, C., McGuire, A. D., Grosse, G., Kuhry, P., Hugelius, G., Lawrence, D. M., Gibson, C., and Sannel, A. B. K.: Permafrost collapse is accelerating carbon release, Nature, 569, 32-34, https://doi.org/10.1038/d41586-01901313-4, 2019.

van der Kamp, G. and Hayashi, M.: The groundwater recharge function of small wetlands in the semi-arid Northern Prairies, Great Plains Res., 8, 39-56, 1998.

van der Kamp, G., Hayashi, M., and Gallen, D.: Comparing the hydrology of a grassed and cultivated catchments in the semi-arid Canadian prairies, Hydrol. Process., 17, 559-575, https://doi.org/10.1002/hyp.1157, 2003.

Vincent, L. A., Zhang, X., Brown, R., Feng, Y., Mekis, E. J., Milewska, E., Wan, H., and Wang, X. L.: Observed trends in Canada's climate and influence of low-frequency variability modes, J. Climate, 28, 4545-4560, https://doi.org/10.1175/JCLID-14-00697.1, 2015

Walker, X. J., Baltzer, J. L., Cumming, S. G., Day, N. J., Goetz, S., Johnstone, J. F., Potter, S., Rogers, B. M., Schuur, E. A. G., Turetsky, M. R., and Mack, M. C.: Increasing wildfires threaten historic carbon sink of boreal forest soils, Nature, 572, 520-523, https://doi.org/10.1038/s41586-019-1474-y, 2019.

Wallace, C. A. and Baltzer, J. L.: Tall shrubs mediate abiotic conditions and plant communities at the treeline-arctic tundra ecotone, Ecosystems, 23, 828-841, https://doi.org/10.1007/s10021019-00435-0, 2019.

Warren, R. K., Pappas, C., Helbig, M., Chasmer, L. E., Berg, A. A., Baltzer, J. L., Quinton, W. L., and Sonnentag, O.: Minor contribution of overstorey transpiration to landscape evapotranspiration in boreal permafrost peatlands, Ecohydrology, 11, e1975, https://doi.org/10.1002/eco.1975, 2018.
Weedon, G. P., Gomes, S., Viterbo, P., Shuttleworth, W. J., Blyth, E., Österle, H., Adam, J. C., Bellouin, N., Boucher, O., and Best, M.: Creation of the WATCH Forcing Data and Its Use to Assess Global and Regional Reference Crop Evaporation over Land during the Twentieth Century, J. Hydrometeorol., 12, 823-848, https://doi.org/10.1175/2011JHM1369.1, 2011.

Weedon, G. P., Balsamo, G., Bellouin, N., Gomes, S., Best, M. J., and Viterbo, P.: The WFDEI meteorological forcing data set: WATCH Forcing Data methodology applied to ERAInterim reanalysis data, Water Resour. Res., 50, 7505-7514, https://doi.org/10.1002/2014WR015638, 2014.

Wheater, H. and Gober, P.: Water security in the Canadian Prairies: Science and management challenges, Philos. T. Roy. Soc. A, 371, 20120409, https://doi.org/10.1098/rsta.2012.0409, 2013.

Wheater, H. S. and Gober, P.: Water security and the science agenda, Water Resour. Res., 51, 5406-5424, https://doi.org/10.1002/2015WR016892, 2015.

Whitman, E., Parisien, M.-A., Thompson, D., and Flannigan, M.: Topoedaphic and forest controls on post-fire vegetation assemblies are modified by fire history and burn severity in the northwestern Canadian boreal forest, Forests, 9, 151, https://doi.org/10.3390/f9030151, 2018.

Wilcox, E. J., Keim, D., de Jong, T., Walker, B., Sonnentag, O., Sniderhan, A. E., Mann, P., and Marsh, P.: Tundra shrub expansion may amplify permafrost thaw by advancing snowmelt timing, Arctic Sci., 5, 202-217, https://doi.org/10.1139/as-20180028, 2019.

Williams, T. J., Quinton, W. L., and Baltzer, J. L.: Linear disturbances on discontinuous permafrost: Implications for thaw-induced changes to land cover and drainage patterns, Environ. Res. Lett., 8, 025006, https://doi.org/10.1088/17489326/8/2/025006, 2013.

Williamson, C., Cameron, K. A., Cook, J. M., Zarsky, J. D., Stibal, M., and Edwards, A.: Glacier algae: a dark past and a darker future, Front. Microbiol., 10, 524, https://doi.org/10.3389/fmicb.2019.00524, 2019.

Williamson, M., Rowlandson, T. L., Berg, A. A., Roy, A., Toose, P., Derksen, C., Arnold, L., and Tetlock, E.: Lband radiometry freeze/thaw validation using air temperature and ground measurements, Remote Sens. Lett., 9, 403-410, https://doi.org/10.1080/2150704X.2017.1422872, 2018.

Woo, M. K. and Rouse, W. R.: MAGS Contribution to Hydrologic and Surface Process Research, in: Cold Region Atmospheric and Hydrologic Studies, The Mackenzie GEWEX Experience, Vol. 2: Hydrologic Processes, edited by: Woo, M., Springer, Berlin, Heidelberg, 8-38, https://doi.org/10.1007/9783-540-75136-6_2, 2008.

Woo, M.-K., Rouse, W. R., Stewart, R. E., and Stone, J. M. R.: The Mackenzie GEWEX Study: A Contribution to Cold Region Atmospheric and Hydrologic Sciences, in: Cold Region Atmospheric and Hydrologic Studies, The Mackenzie GEWEX Experience, Vol. 1: Atmospheric Dynamics, edited by: Woo, M. K., Springer-Verlag, Berlin, Heidelberg, 1-22, https://doi.org/10.1007/978-3-540-73936-4_1, 2008.

WWF - World Wildlife Fund: Canada's Rivers at Risk - Environmental Flows and Canada's Freshwater Future, WWF-Canada, Toronto, Ontario, Canada, 30 pp., available at: http://www.wwf. ca/?4820 (last access: 6 April 2021), 2009. 
Yang, D., Shi, X., and Marsh, P.: Variability and extreme of Mackenzie River daily discharge during 1973-2011, Quatern. Int., 380-381, 159-168, https://doi.org/10.1016/j.quaint.2014.09.023, 2015.

Yassin, F., Razavi, S., Wheater, H., Sapriza-Azuri, G., Davison, B., and Pietroniro, A.: Enhanced identification of a hydrologic model using streamflow and satellite water storage data: A multicriteria sensitivity analysis and optimization approach, Hydrol. Process., 31, 3320-3333, https://doi.org/10.1002/hyp.11267, 2017.

Yassin, F., Razavi, S., Elshamy, M., Davison, B., Sapriza-Azuri, G., and Wheater, H.: Representation and improved parameterization of reservoir operation in hydrological and landsurface models, Hydrol. Earth Syst. Sci., 23, 3735-3764, https://doi.org/10.5194/hess-23-3735-2019, 2019.

Young, A. M., Higuera, P. E., Duffy, P. A., and Hu, F. S.: Climatic thresholds shape northern high-latitude fire regimes and imply vulnerability to future climate change, Ecography, 40, 606-617, https://doi.org/10.1111/ecog.02205, 2017.

Zemp, M., Frey, H., Gärtner-Roer, I., Nussbaumer, S., Hoelzle, M., Paul, F., Haeberli, W., Denzinger, F., Ahlstrøm, A. P., Anderson, B., Bajracharya, S., Baroni, C., Braun, L. N., Cáceres, B. E., Casassa, G., Cobos, G., Dávila, L. R., Granados, H. D., Demuth, M. N., Espizua, L., Fischer, A., Fujita, K., Gadek, B., Ghazanfar, A., Ove Hagen, J., Holmlund, P., Karimi, N., Li, Z., Pelto, M., Pitte, P., Popovnin, V. V., Portocarrero, C. A., Prinz, R., Sangewar, C. V., Severskiy, I., Sigurđsson, O., Soruco, A., Usubaliev, R., and Vincent, C: Historically unprecedented global glacier decline in the early 21 st century, J. Glaciol., 61, 745-762, https://doi.org/10.3189/2015JoG15J017, 2015.
Zha, T., Barr, A. G., van der Kamp, G., Black, T. A., McCaughey, J. H., and Flanagan, L. B.: Interannual variation of evapotranspiration from forest and grassland ecosystems in western Canada in relation to drought, Agr. Forest Meteorol., 150, 1476-1484, https://doi.org/10.1016/j.agrformet.2010.08.003, 2010.

Zwieback, S., Westermann, S., Langer, M., Boike, J., Marsh, P., and Berg, A.: Improving permafrost modeling by assimilating remotely sensed soil moisture, Water Resour. Res., 55, 1814-1832, https://doi.org/10.1029/2018WR023247, 2019a.

Zwieback, S., Chang, Q., Marsh, P., and Berg, A.: Shrub tundra ecohydrology: rainfall interception is a major component of the water balance, Environ. Res. Lett., 14, 055005, https://doi.org/10.1088/1748-9326/ab1049, 2019b. 